\title{
Biogenic secondary organic aerosol over the United States: Comparison of climatological simulations with observations
}

\author{
Hong Liao, ${ }^{1}$ Daven K. Henze, ${ }^{2}$ John H. Seinfeld,${ }^{3}$ Shiliang Wu,${ }^{4}$ and Loretta J. Mickley ${ }^{4}$ \\ Received 21 July 2006; revised 4 October 2006; accepted 2 November 2006; published 16 March 2007.
}

[1] Understanding the effects of global climate change on regional air quality is central in future air quality planning. We report here on the use of the Goddard Institute for Space Studies (GISS) general circulation model (GCM) III to drive the GEOS-CHEM global atmospheric chemical transport model to simulate climatological present-day aerosol levels over the United States. Evaluation of model predictions using surface measurements from the Interagency Monitoring of Protected Visual Environments (IMPROVE) network indicates that the GISS GCM III/GEOS-CHEM model is a suitable tool for simulating aerosols over the United States in the present climate. The model reproduces fairly well the concentrations of sulfate (mean bias of $-0.36 \mu \mathrm{g} \mathrm{m}^{-3}$, normalized mean bias (NMB) of $-25.9 \%$ ), black carbon $\left(-0.004 \mu \mathrm{g} \mathrm{m}^{-3},-1.9 \%\right)$, organic carbon that comprises primary and secondary components $\left(-0.56 \mu \mathrm{g} \mathrm{m}^{-3},-34.2 \%\right)$, and $\mathrm{PM}_{2.5}$ $\left(-0.87 \mu \mathrm{g} \mathrm{m}^{-3},-20.4 \%\right)$. Nitrate concentrations are overpredicted in the western United States (west of $95^{\circ} \mathrm{W}$ ) with a NMB of $+75.6 \%$ and underestimated in the eastern United States with a NMB of $-54.4 \%$. Special attention is paid to biogenic secondary organic aerosol (SOA). The highest predicted seasonal mean SOA concentrations of $1-2 \mu \mathrm{g} \mathrm{m}^{-3}$ and $0.5-1.5 \mu \mathrm{g} \mathrm{m}^{-3}$ are predicted over the northwestern and southeastern United States, respectively, in the months of June-July-August. Isoprene is predicted to contribute $49.5 \%$ of the biogenic SOA burden over the United States, with the rest explained by the oxidation of terpenes. Predicted biogenic SOA concentrations are in reasonable agreement with inferred SOA levels from IMPROVE measurements. On an annual basis, SOA is predicted to contribute $10-20 \%$ of $\mathrm{PM}_{2.5}$ mass in the southeastern United States, as high as 38\% in the northwest and about $5-15 \%$ in other regions, indicating the important role of SOA in understanding air quality and visibility over the United States.

Citation: Liao, H., D. K. Henze, J. H. Seinfeld, S. Wu, and L. J. Mickley (2007), Biogenic secondary organic aerosol over the United States: Comparison of climatological simulations with observations, J. Geophys. Res., 112, D06201, doi:10.1029/2006JD007813.

\section{Introduction}

[2] Understanding the effects of global climate change on regional air quality is central in future air quality planning. The principal change in global climate will be driven by greenhouse gases, although ozone and aerosol levels will be affected by, and will affect, future climate, which is simulated by general circulation models (GCMs). While some GCMs do contain detailed treatments of gas phase chemis-

\footnotetext{
${ }^{1}$ State Key Laboratory of Atmospheric Boundary Physics and Atmospheric Chemistry, Institute of Atmospheric Physics, Chinese Academy of Sciences, Beijing, China.

${ }^{2}$ Department of Chemical Engineering, California Institute of Technology, Pasadena, California, USA.

${ }^{3}$ Department of Chemical Engineering and Department of Environmental Science and Engineering, California Institute of Technology, Pasadena, California, USA.

${ }^{4}$ Division of Engineering and Applied Sciences and Department of Earth and Planetary Sciences, Harvard University, Cambridge, Massachusetts, USA.
}

Copyright 2007 by the American Geophysical Union. 0148-0227/07/2006JD007813 try and aerosols [e.g., Liao et al., 2006], a strategy based on using a GCM focused on representing meteorological processes to drive an atmospheric chemical transport model (ACTM) is ideally suited to evaluate effects of climate change on air quality. As a prelude to such studies, it is important to establish the ability of the GCM/ACTM combination to replicate present climatological air quality.

[3] In the present work we employ the Goddard Institute for Space Studies (GISS) GCM III [Rind et al., 2007] with high temporal resolution meteorological fields to drive the GEOS-CHEM global atmospheric chemical transport model, a state-of-the-science global model of atmospheric composition (http://www.as.harvard.edu/chemistry/trop/ geos). The GEOS-CHEM simulations of ozone, sulfate/ nitrate/ammonium, and carbonaceous aerosols driven by NASA/GEOS assimilated meteorological data have been evaluated extensively in the United States with surface and airborne observations [Fiore et al., 2002, 2003; Li et al., 2002, 2004; Park et al., 2003, 2004, 2006]. The interface of GISS GCM III with GEOS-CHEM and the simulation of present-day ozone are reported by $W u$ et al. [2007]. The 
Table 1. Representation of Secondary Organic Aerosol Formation in Regional and Global Models

\begin{tabular}{|c|c|c|c|}
\hline Source & Hydrocarbons Considered & Gas-Aerosol Partitioning & Regions Simulated \\
\hline Chung and Seinfeld [2002] & 14 terpenes & two-product model & global \\
\hline Derwent et al. [2003] & $\alpha$-pinene & $\begin{array}{l}\text { first-order scavenging of } \\
\text { condensable oxidation } \\
\text { products }\end{array}$ & global \\
\hline Tsigaridis and Kanakidou [2003] & $\begin{array}{l}\alpha \text { - and } \beta \text {-pinene } \\
\text { toluene and xylene }\end{array}$ & two-product model & global \\
\hline Lack et al. [2004] & $\begin{array}{l}\text { biogenic } \mathrm{C}_{10} \mathrm{H}_{16} \text { and } \\
\text { anthropogenic } \mathrm{C}_{4} \mathrm{H}_{10}\end{array}$ & bulk yield and two-product model & global \\
\hline Bonn et al. [2004] & $\alpha$-pinene & $\begin{array}{l}\text { aerosol forms when } \\
\text { saturation vapor pressure } \\
\text { of species is exceeded }\end{array}$ & global \\
\hline Tsigaridis et al. [2005] & $\begin{array}{c}\alpha \text { - and } \beta \text {-pinene, toluene, } \\
\text { xylene, and isoprene }\end{array}$ & two-product model & global \\
\hline Henze and Seinfeld [2006] & 14 terpenes, isoprene & two-product model & global \\
\hline Andersson-Sköld and Simpson [2001] & $\alpha$-pinene & two-product model & northern Europe \\
\hline Griffin et al. [2002] & aromatics, terpenes & explicit organic chemistry & southern California \\
\hline Heald et al. [2005] & 14 terpenes & two-product model & northwestern Pacific Ocean \\
\hline This work & 14 terpenes, isoprene & two-product model & United States \\
\hline
\end{tabular}

present work represents the first simulation of aerosols using this GISS GCM III/GEOS-CHEM model.

[4] The goal of this work is to simulate climatological present-day aerosol levels over the United States using the GISS GCM III/GEOS-CHEM combination and compare these to available surface data. We focus especially, but not exclusively, on the organic portion of the aerosol. Organic aerosol (OA) is a significant constituent of particulate matter (PM) globally and in the United States [U.S. Environmental Protection Agency, 2004]. Primary OA (POA) refers to OA emitted directly into the atmosphere, whereas secondary OA (SOA) is formed in the atmosphere upon oxidation of a number of volatile organic compounds (VOC) [Seinfeld and Pankow, 2003]. Both anthropogenic and biogenic VOCs are precursors to SOA; on a global scale, biogenic hydrocarbons are estimated to be the predominant source [Tsigaridis and Kanakidou, 2003; Lack et al., 2004; Kanakidou et al., 2005]. In the present work we focus on biogenic SOA. It should be noted that anthropogenic VOCs, especially aromatic hydrocarbons, have recently been suggested as possibly playing a role as a source of SOA at the regional scale [de Gouw et al., 2005]. An evaluation of the contribution of aromatic VOCs to SOA over the United States will be the subject of forthcoming work.

[5] There have been a number of modeling studies that simulate SOA regionally [Andersson-Sköld and Simpson, 2001; Griffin et al., 2002; Heald et al., 2005] and globally [Chung and Seinfeld, 2002; Derwent et al., 2003; Tsigaridis and Kanakidou, 2003; Bonn et al., 2004; Lack et al., 2004; Tsigaridis et al., 2005; Henze and Seinfeld, 2006]. The modeling approach and hydrocarbons considered in these studies are listed in Table 1. Most studies considered only biogenic SOA from the oxidation of terpenes and did not account for the formation of SOA from isoprene when the models were used to interpret and understand measured OA concentrations in the atmosphere. Tsigaridis et al. [2005] included isoprene as a source of SOA with an oversimplified approach of a constant yield. Although Henze and Seinfeld [2006] simulated global SOA burden with SOA formation from isoprene, they did not apply the model to examine organic aerosols over the United States.
[6] In this work we investigate biogenic SOA over the United States accounting for the formation of SOA from the oxidation of both terpenes and isoprene. We begin with a description of the model in section 2. In section 3.1, organic aerosol levels simulated by the GEOS-CHEM model driven by meteorology from the GISS GCM III are evaluated using surface measurements from the Interagency Monitoring of Protected Visual Environments (IMPROVE) network. We study the sensitivity of SOA formation to predicted POA concentrations and examine the predicted contribution to SOA by different biogenic VOC classes. Predicted inorganic aerosol levels are evaluated against IMPROVE data in section 3.2. The predicted contribution of SOA to fine aerosol mass is investigated in section 3.3.

\section{Model Description}

\subsection{GISS GCM/GEOS-CHEM Mode}

[7] We simulate aerosols using the chemical transport model GEOS-CHEM (version 7.3.3, http://www.as.harvard. edu/chemistry/trop/geos/index.html) driven by meteorological fields from the GISS GCM III, which is an updated version of the GCM used by Rind et al. [1999]. The GCM and the GEOS-CHEM models have horizontal resolution of $4^{\circ}$ latitude by $5^{\circ}$ longitude, with 23 vertical layers extending from the surface to $0.002 \mathrm{hPa}(\sim 85 \mathrm{~km}$ altitude). Archived GCM data for GEOS-CHEM include 6-hour averages of winds, convective mass fluxes, temperature, humidity, cloud optical depths, and cloud fractions, as well as 3-hour averages of mixing depths and surface variables (precipitation, winds at 10-m altitude, temperature, albedo, and solar radiation)

[8] The GEOS-CHEM includes a fully coupled treatment of tropospheric ozone- $\mathrm{NO}_{\mathrm{x}}-\mathrm{VOC}$ chemistry and sulfate/ nitrate/ammonium, black carbon (BC), and OA. Chemical tracers in version 7.3.3 of the GEOS-CHEM are listed in Table 2. Simulation of black carbon and POA in GEOSCHEM is described by Park et al. [2003] and the implementation of sulfate/nitrate/ammonium is described by Park et al. [2004]. Aerosol and gas phase simulations are coupled through formation of sulfate and nitrate, heterogeneous chemistry, aerosol effects on photolysis rates [Martin et 
Table 2. Chemical Tracers

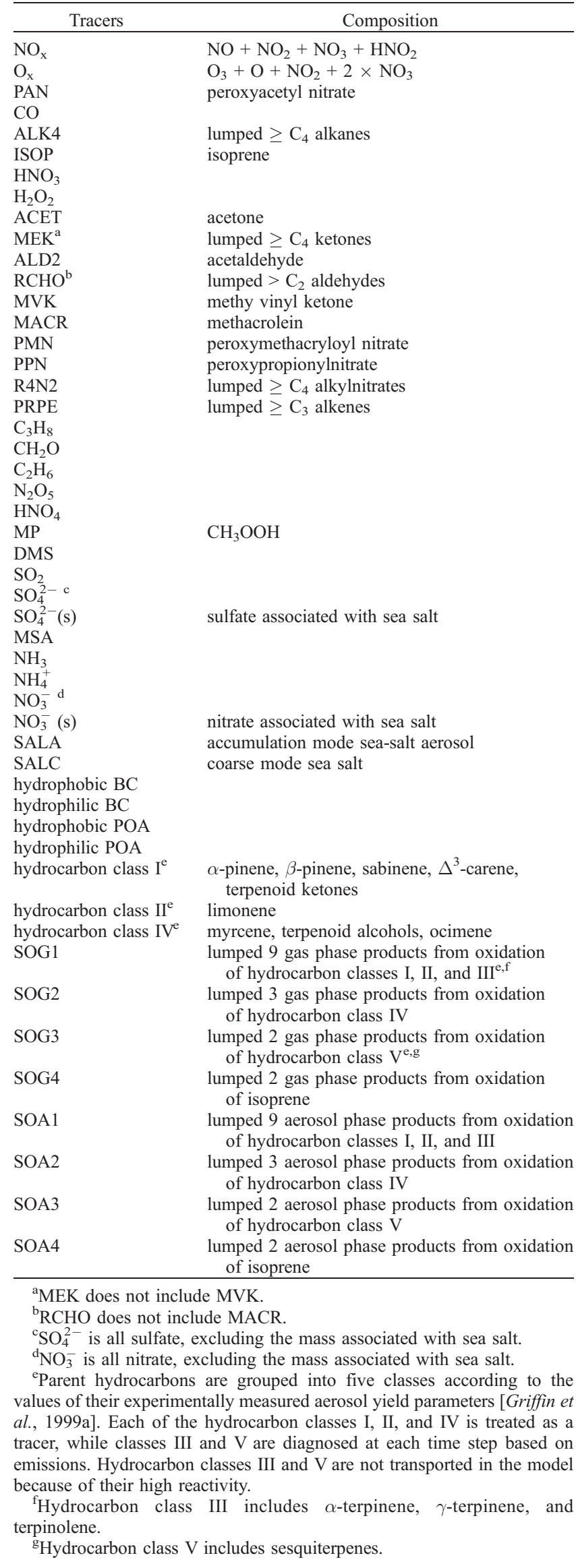

al., 2003], and SOA formation. Heterogeneous reactions include hydrolysis of $\mathrm{N}_{2} \mathrm{O}_{5}$ on different types of aerosols [Evans and Jacob, 2005] and irreversible absorption of $\mathrm{NO}_{3}, \mathrm{NO}_{2}$ and $\mathrm{HO}_{2}$ on wet aerosols [Jacob, 2000]. We do not consider sea salt and mineral dust aerosols in this work; heterogeneous reactions occur only on surfaces of sulfate, BC, and OA. Partitioning of total ammonia and nitric acid between the gas and aerosol phases is calculated using the ISORROPIA thermodynamic equilibrium model [Nenes et al., 1998].

\subsection{Simulation of SOA Formation}

[9] Formation of SOA in the GEOS-CHEM model is predicted based upon rate constants and aerosol yield parameters determined from laboratory chamber studies [Seinfeld and Pankow, 2003]. SOA formation from isoprene photooxidation follows the work of Henze and Seinfeld [2006], which is based on chamber experiments of reaction of isoprene with $\mathrm{OH}$ at low $\mathrm{NO}_{\mathrm{x}}$ condition [Kroll et al., 2006]. Simulation of SOA from monoterpenes and other reactive VOCs (ORVOCs) is described by Chung and Seinfeld [2002]; for computational efficiency we have reduced the number of tracers from 33 in that work to 9 by lumping oxidation products together. As in the work by Chung and Seinfeld [2002], monoterpenes and ORVOCs are divided into five hydrocarbon classes (listed in Table 2) according to the values of their experimentally measured aerosol yield parameters [Griffin et al., 1999a]. In this study, each of the hydrocarbon classes I, II and IV is treated as a tracer, while classes III and V are diagnosed at each time step based on emissions. Hydrocarbon classes III and V are not transported in the model because of their high reactivity. For each of the first four primary reactive hydrocarbon classes, there are three oxidation products, two for combined $\mathrm{O}_{3}$ and $\mathrm{OH}$ oxidation and one for $\mathrm{NO}_{3}$ oxidation. In the case of hydrocarbon class $\mathrm{V}$ (sesquiterpenes), only two products are required (one for combined $\mathrm{O}_{3}$ and $\mathrm{OH}$ oxidation and one for $\mathrm{NO}_{3}$ oxidation). All products are semivolatile and partition between the gas and aerosol phases, leading to a total of 28 oxidation products. During chemistry simulation, the chemical reactions and the number of SOA-related species in the GEOS-CHEM are exactly the same as those of Chung and Seinfeld [2002]. When the chemistry calculation is finished, the gas phase products from the oxidation of hydrocarbon classes I, II, and III are lumped into one tracer, because they will have the same behavior during transport since they are assumed to have the same molecular weight and Henry's law constant. The mass ratios of the individual oxidation products to the total mass of lumped products in each grid cell are then used to partition the tracer back into individual products before the chemistry simulation of the next time step. Similarly, we aggregate all the aerosol phase products from the oxidation of hydrocarbon classes I, II, and III into one tracer, and treat the gas phase and aerosol phase oxidation products from each of hydrocarbon group IV, hydrocarbon group $\mathrm{V}$, and isoprene as one tracer. The composition of each tracer is given in Table 2 .

\subsection{Dry and Wet Deposition}

[10] The wet deposition scheme for aerosols follows that of Liu et al. [2001], which includes scavenging in convec- 
Table 3. Annual Emissions of Ozone Precursors and Aerosols/ Aerosol Precursors

\begin{tabular}{|c|c|c|}
\hline Species & Global & $\begin{array}{l}\text { Contiguous } \\
\text { United States }\end{array}$ \\
\hline $\mathrm{NO}_{\mathrm{x}}, \mathrm{Tg} \mathrm{N} \mathrm{yr}^{-1}$ & 43.77 & 6.98 \\
\hline Fossil fuel combustion & 23.50 & 6.27 \\
\hline Biomass burning & 6.49 & 0.04 \\
\hline Biofuel & 2.22 & 0.01 \\
\hline Soil & 6.25 & 0.43 \\
\hline Lightning & 4.80 & 0.09 \\
\hline Aircraft & 0.51 & 0.14 \\
\hline $\mathrm{CO}, \mathrm{Tg} \mathrm{CO} \mathrm{yr}^{-1}$ & 1041.28 & 95.22 \\
\hline Fossil fuel combustion & 406.08 & 87.81 \\
\hline Biofuel & 175.67 & 3.11 \\
\hline Biomass burning & 459.53 & 4.30 \\
\hline Isoprene vegetation, ${\mathrm{Tg} \mathrm{C} \mathrm{yr}^{-1}}^{-1}$ & 418.38 & 30.52 \\
\hline Monoterpenes vegetation, ${\mathrm{Tg} \mathrm{C} \mathrm{yr}^{-1}}^{-1}$ & 117.22 & 9.49 \\
\hline Ethane, $\mathrm{Tg} \mathrm{C} \mathrm{yr}^{-1}$ & 10.67 & 1.10 \\
\hline Industrial & 6.72 & 1.08 \\
\hline Biomass burning & 1.92 & 0.02 \\
\hline Biofuel & 2.03 & 0.00 \\
\hline Propane, $\mathrm{Tg} \mathrm{C} \mathrm{yr}{ }^{-1}$ & 11.65 & 1.63 \\
\hline Industral & 10.07 & 1.62 \\
\hline Biomass burning & 0.66 & 0.01 \\
\hline Biofuel & 0.92 & 0.00 \\
\hline$\geq \mathrm{C}_{4}$ alkanes, $\mathrm{Tg} \mathrm{C} \mathrm{yr}^{-1}$ & 25.11 & 6.19 \\
\hline Industrial & 23.72 & 6.18 \\
\hline Biomass burning & 0.64 & 0.01 \\
\hline Biofuel & 0.75 & 0.00 \\
\hline$\geq \mathrm{C}_{3}$ alkenes, $\mathrm{Tg} \mathrm{C} \mathrm{yr}^{-1}$ & 29.68 & 1.81 \\
\hline Industrial & 7.56 & 0.89 \\
\hline Biomass burning & 3.91 & 0.04 \\
\hline Biofuel & 6.24 & 0.01 \\
\hline Biogenic sources & 11.97 & 0.87 \\
\hline Acetone, $\mathrm{Tg} \mathrm{C} \mathrm{yr}^{-1}$ & 45.53 & 2.49 \\
\hline Industrial & 0.67 & 0.17 \\
\hline Biomass burning & 3.12 & 0.03 \\
\hline Biofuel & 0.25 & 0.00 \\
\hline Biogenic sources & 41.49 & 2.29 \\
\hline $\mathrm{SO}_{2}, \mathrm{Tg} \mathrm{S} \mathrm{yr}^{-1}$ & 70.52 & 8.62 \\
\hline Industrial & 59.24 & 8.59 \\
\hline Biomass burning & 1.22 & 0.01 \\
\hline Biofuel & 0.27 & 0.00 \\
\hline Volcanoes & 5.49 & 0.00 \\
\hline Aircraft & 0.07 & 0.02 \\
\hline Ship & 4.23 & 0.00 \\
\hline \multicolumn{3}{|l|}{ DMS, $\operatorname{Tg~S~yr}^{-1}$} \\
\hline Oceanic source & 14.04 & 0.00 \\
\hline $\mathrm{NH}_{3}, \mathrm{Tg} \mathrm{N} \mathrm{yr}{ }^{-1}$ & 55.00 & 3.04 \\
\hline Industrial & 33.31 & 2.21 \\
\hline Biomass burning & 5.86 & 0.05 \\
\hline Biofuel & 1.61 & 0.18 \\
\hline Natural & 14.22 & 0.60 \\
\hline 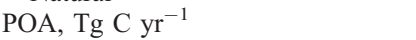 & 33.12 & 1.62 \\
\hline Industrial & 2.69 & 0.51 \\
\hline Biomass burning & 23.38 & 0.23 \\
\hline Biofuel & 7.05 & 0.88 \\
\hline $\mathrm{BC}, \mathrm{Tg} \mathrm{C} \mathrm{\textrm {yr } ^ { - 1 }}$ & 7.93 & 0.68 \\
\hline Industrial & 3.45 & 0.60 \\
\hline Biomass burning & 2.85 & 0.02 \\
\hline Biofuel & 1.63 & 0.06 \\
\hline
\end{tabular}

tive updrafts, rainout and washout from convective anvils and large-scale precipitation, and return to the atmosphere following evaporation. It has been extended to predict wet deposition of soluble gases on the basis of effective Henry's law partitioning in warm clouds, retention efficiency upon droplet freezing in mixed clouds, and surface coating or cocondensation of ice crystals in cold clouds [Mari et al., 2000]. For the scavenging of aerosols, sulfate, ammonium, nitrate, and hydrophilic POA and
$\mathrm{BC}$ aerosols are assumed to be fully soluble. Hydrophobic POA and BC are assumed to be insoluble. Following Cooke et al. [1999], we assume that ambient conversion of POA and BC from hydrophobic to hydrophilic occurs with an exponential decay lifetime of 1.15 days. For SOA, $80 \%$ is assumed to dissolve into clouds, consistent with findings of Limbeck and Puxbaum [2000]. Dry deposition of aerosols and gases is based on a standard resistance-in-series model dependent on local surface type and meteorological conditions [Wesely, 1989] and implemented as described by Wang et al. [1998].

\subsection{Emissions}

[11] Table 3 summarizes global and contiguous United States (excluding Alaska and Hawaii) emissions of ozone precursors and aerosols/aerosol precursors used in this version of the GEOS-CHEM model. These emissions are representative of conditions in mid to late 1990s and early 2000s. Emissions of ozone precursors follow those of $W u$ et al. [2007]. Sulfur and ammonia emissions are based on those of Park et al. [2004]. Emissions of anthropogenic BC and POA over North America are taken from Cooke et al. [1999], with seasonality following Park et al. [2003]. Global biofuel emissions of BC and POA are from Yevich and Logan [2003] with updates described by Park et al. [2003]. Biomass burning emissions of BC and POA are calculated using the global biomass burning inventory of Duncan et al. [2003]. We assume that $80 \%$ of BC and $50 \%$ of POA emitted from all primary sources are hydrophobic [Cooke et al., 1999; Chung and Seinfeld, 2002]. Annual distributions of POA emissions from fossil fuel, biomass burning, and biofuel over the United States are shown in Figure 1.

[12] We calculate global monoterpene and isoprene emission fluxes using the formulations of Guenther et al. [1995]. The emission scheme uses a global surface type of Olson [1992] that distinguishes among 56 ecosystems. Guenther et al. [1995] assigned to each of the 56 ecosystems a base monoterpene (or isoprene) emission flux per unit leaf area at $30^{\circ} \mathrm{C}$ for a photosynthetically active radiation flux of $1000 \mu \mathrm{mol} \mathrm{m} \mathrm{m}^{-2} \mathrm{~s}^{-1}$. The emissions of monoterpenes (or isoprene) are then calculated based on vegetation type, monthly adjusted leaf area index, and locally predicted temperature and radiation. The calculation of leaf area index follows the treatment in Wang et al. [1998]. Predicted present-day global mono-

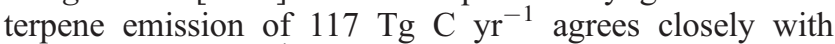
the $127 \mathrm{Tg} \mathrm{C} \mathrm{yr}^{-1}$ reported by Guenther et al. [1995]. Our predicted global isoprene emission of $418 \mathrm{Tg} \mathrm{C} \mathrm{yr}^{-1}$ is lower than the $506 \mathrm{Tg} \mathrm{C} \mathrm{yr}^{-1}$ estimated by Guenther et al. [1995] and close to the lower end of the isoprene

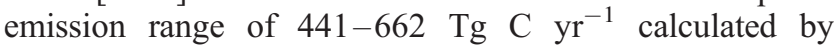
Model of Emissions of Gases and Aerosols from Nature (MEGAN) in the work of Guenther et al. [2006]. Monthly emission inventories of biogenic ORVOCs are taken from the Global Emissions Inventory Activity (GEIA). To obtain the instantaneous emission rates of ORVOCs, monthly averages are scaled by the solar zenith angle. Geographical distributions of annual biogenic emissions of monoterpenes, ORVOCs, and isoprene over the United States are given in Figure 2. The splitting of 
(a)

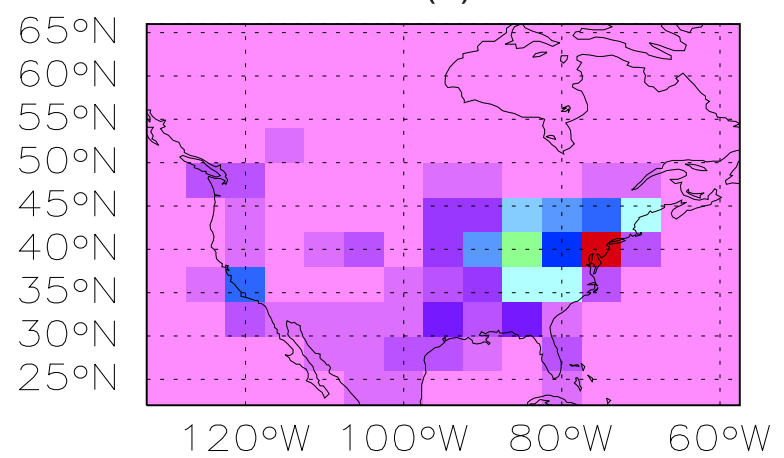

(b)

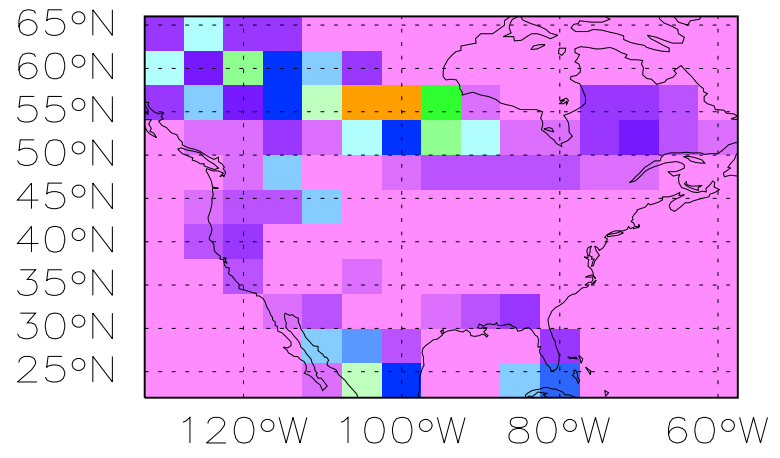

(c)
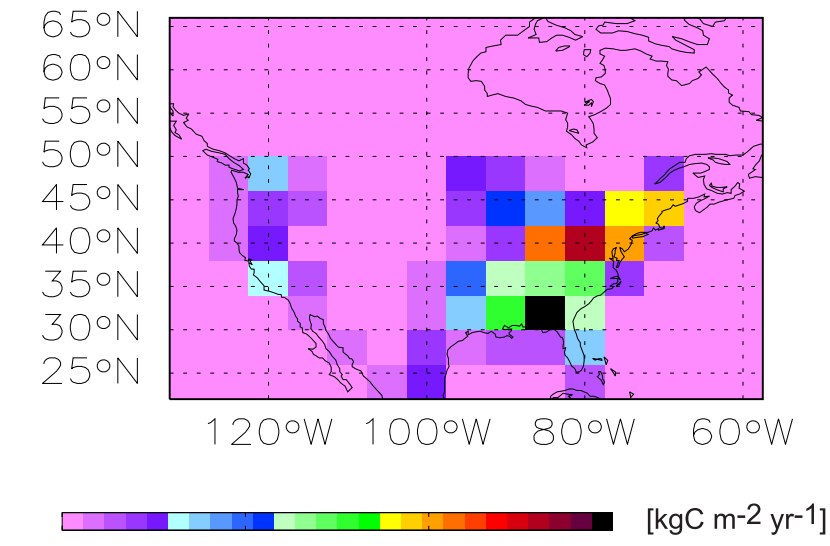

$0.00 e+00 \quad 1.33 e-04 \quad 2.67 e-04 \quad 4.00 e-04$

Figure 1. Geographical distributions of annual POA emissions $\left(\mathrm{kgC} \mathrm{m}^{-2} \mathrm{yr}^{-1}\right)$ from (a) fossil fuel, (b) biomass burning, and (c) biofuel.

monoterpenes and ORVOCs into the five hydrocarbon classes was described by Griffin et al. [1999b].

\section{Simulated Aerosols Over the United States}

[13] Predicted ozone and its precursors in the GISS/ GEOS-CHEM model are presented and evaluated by $\mathrm{Wu}$ et al. [2007]. We focus here on simulated aerosol concentrations over the United States, and evaluate predictions of all aerosol species by comparisons with IMPROVE measurements. Since the GCM simulates a representative ensemble of possible meteorological years, we average the GCM/GEOS-CHEM predictions over a 3-year period following 6 months of initial spin-up. The IMPROVE measurements over years 2001-2003 are averaged to represent aerosol climatology.

\subsection{Predicted Organic Carbon Aerosols}

\subsubsection{Distributions of POA and SOA}

[14] Figure 3 presents predicted present-day seasonal and annual mean surface layer POA and SOA concentrations over the United States. POA in the GEOS-CHEM model is simulated as carbon mass, which is converted to organic mass using a factor of 1.4 to be consistent with the

(a)

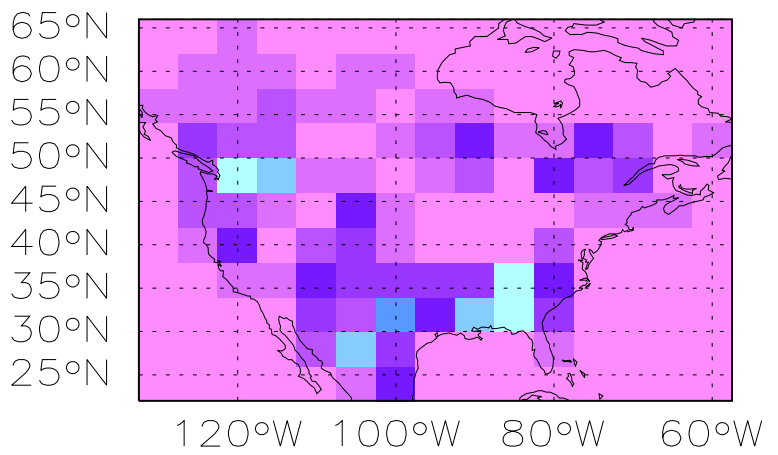

(b)

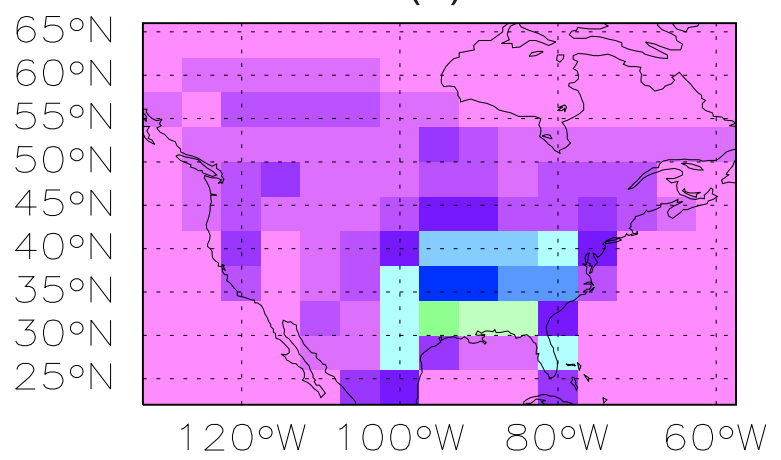

(c)

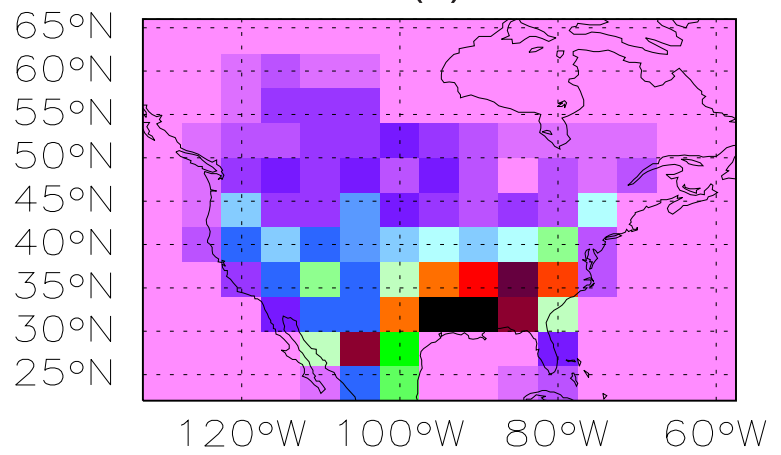

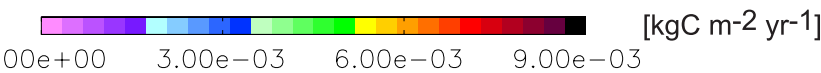

Figure 2. Estimated annual biogenic emissions $\left(\mathrm{kgC} \mathrm{m}^{-2}\right.$ $\mathrm{yr}^{-1}$ ) of (a) monoterpenes, (b) ORVOCs, and (c) isoprene based on the work of Guenther et al. [1995]. 
(a)
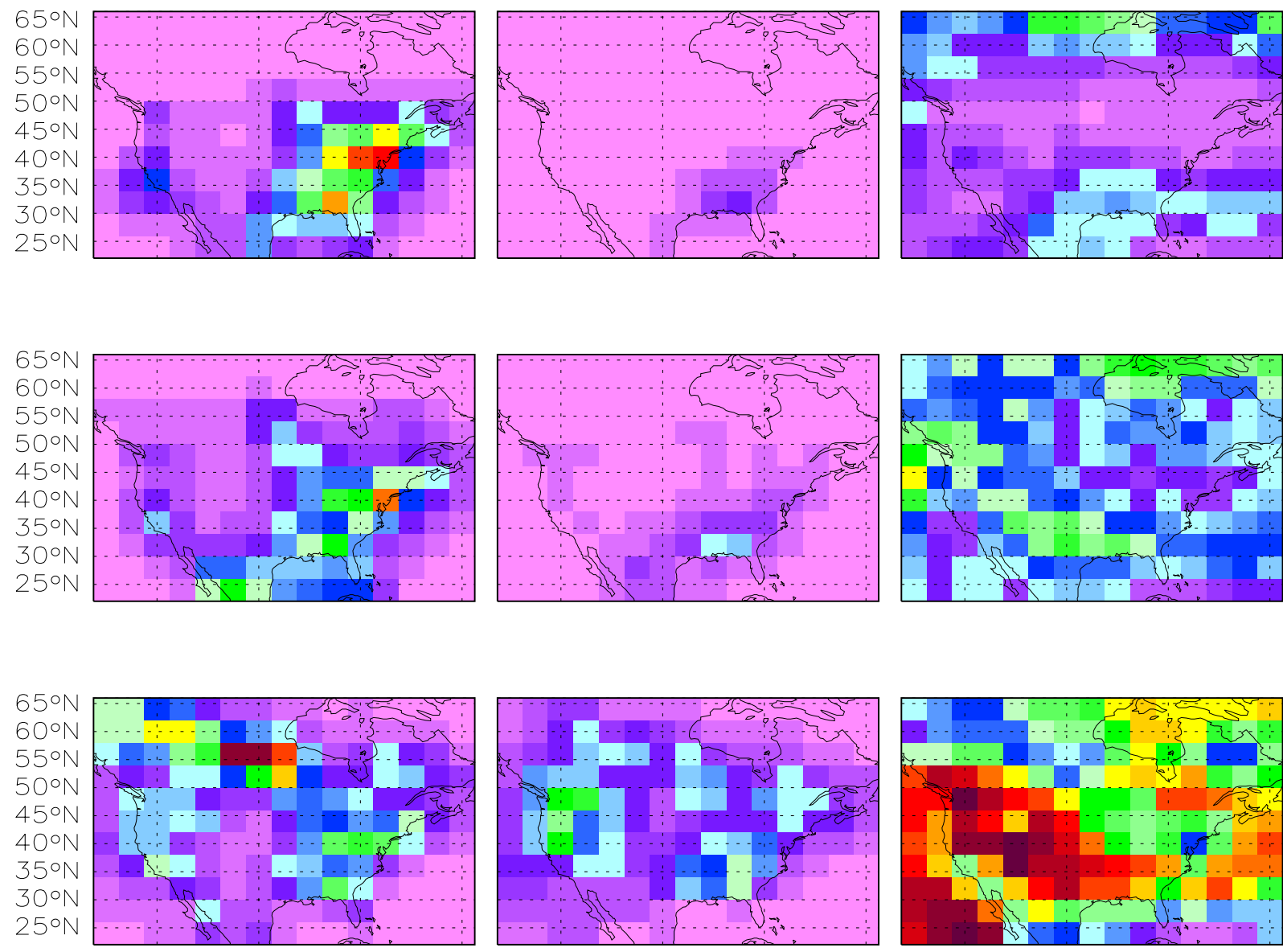

(c)
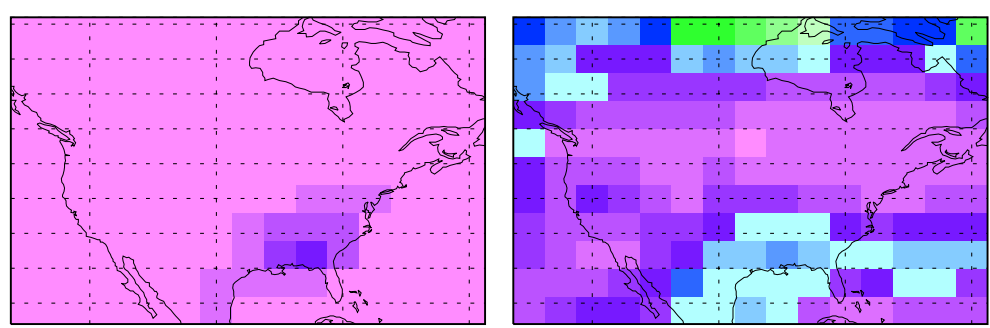

DJF
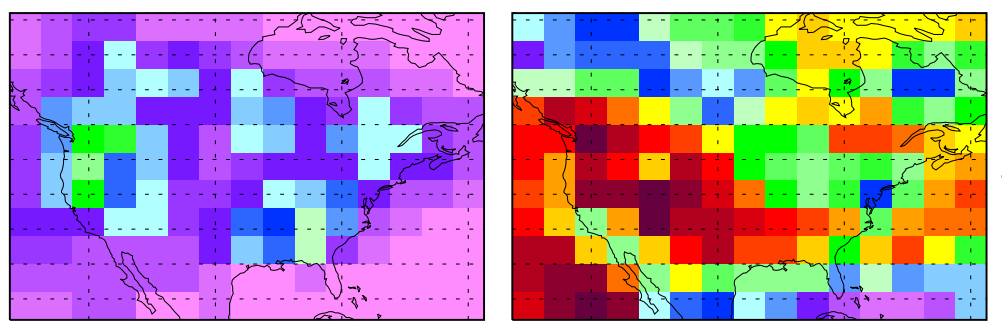
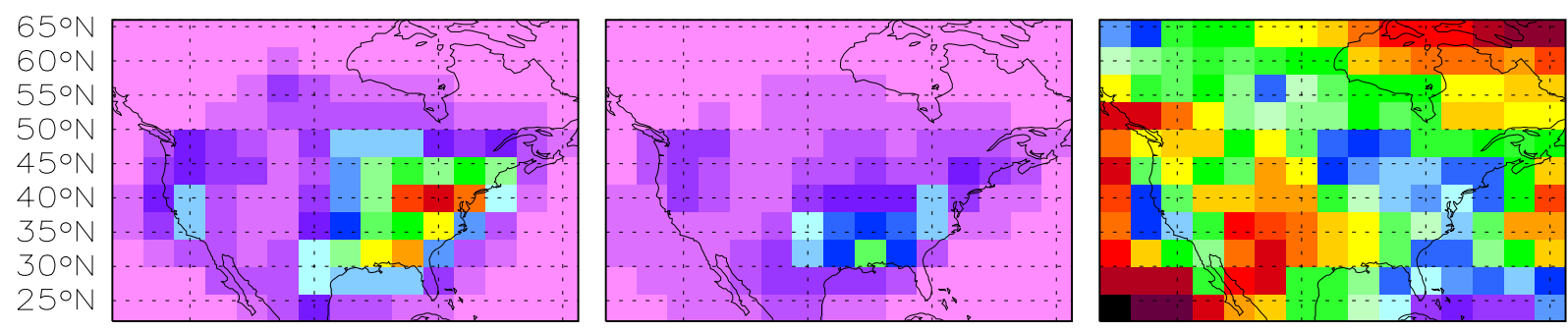

SON
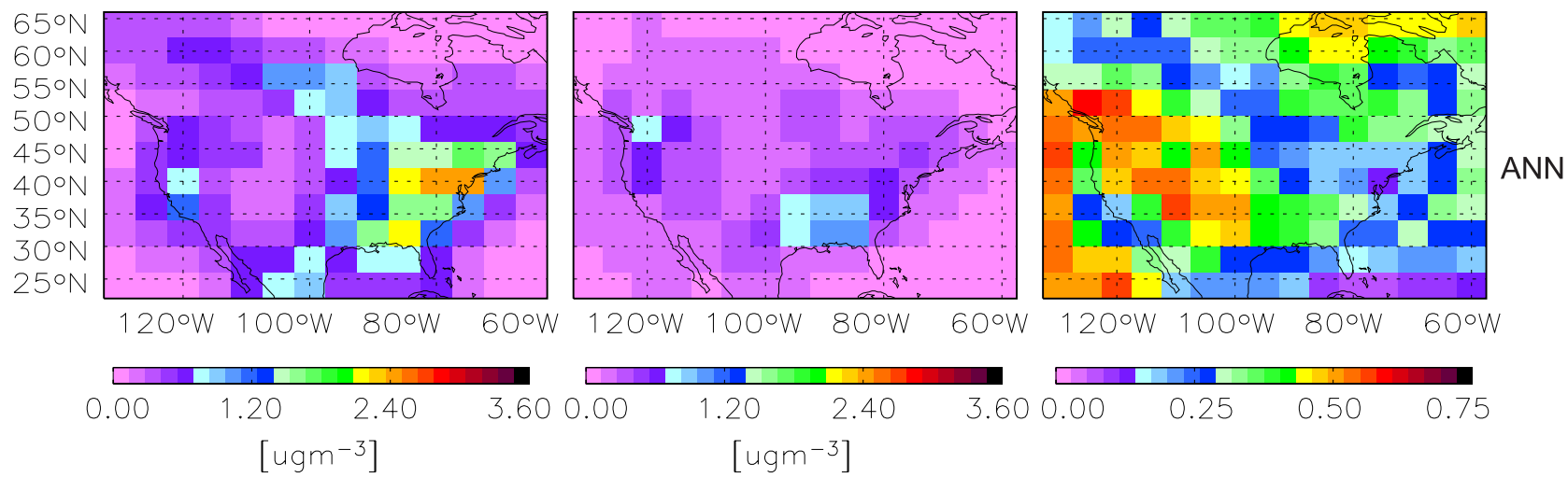

Figure 3. Predicted seasonal and annual mean surface layer of (a) concentrations of POA $\left(\mu \mathrm{g} \mathrm{m}^{-3}\right)$, (b) concentrations of SOA $\left(\mu \mathrm{g} \mathrm{m}^{-3}\right)$, and (c) ratios of SOA to OA (POA + SOA). 
assumption used for converting IMPROVE measurements. POA concentrations are generally higher in the eastern than in the western United States. Over the eastern United States, the highest POA concentrations of about $3 \mu \mathrm{g} \mathrm{m}^{-3}$ are predicted to occur in September-October-November (SON) and December-January-Februrary (DJF), reflecting the seasonal variation of fossil fuel and biofuel emissions. In the western United States, POA concentrations can reach about $1 \mu \mathrm{g} \mathrm{m}^{-3}$ in summer because of the seasonal maxima of forest fires in May-September.

[15] With the largest biogenic emissions occurring in June-July-August (JJA), SOA concentrations of $0.5-$ $2 \mu \mathrm{g} \mathrm{m}^{-3}$ are predicted over the southeastern and northwestern United States, while levels of $0.5-1.0 \mu \mathrm{g} \mathrm{m}^{-3}$ are predicted over the northeast and north central part of the country. SOA is predicted to contribute $50-75 \%$ of OA in the western and southern United States and $25-50 \%$ of OA in other regions in JJA (Figure 3c). In DJF, SOA to OA ratios are generally predicted to be smaller than $10 \%$, except for the ratios of $10-20 \%$ near the southern borders. Predicted SOA to OA ratios in JJA in the Northeast agree with those of Millet et al. [2005], who determined that, on average, $37 \%$ of $\mathrm{OA}$ is secondary in origin during summer based upon measurements from the Pittsburgh Air Quality Study (PAQS) during year 2002. The predicted winter SOA to OA ratios of less than $10 \%$ are, however, lower than the $16 \%$ reported by Millet et al. [2005].

[16] To study the vertical distributions of POA and SOA over the United States, we show in Figure 4 for DJF and JJA the altitude-latitude plots of POA concentration, SOA mass, and the ratio of SOA to OA that are zonally averaged over $130^{\circ}-65^{\circ} \mathrm{W}$. POA concentrations drop rapidly with height in both DJF and JJA. As a result of the strong convection in hot seasons, POA can reach higher altitude in JJA than in DJF. Although SOA concentrations are very small in DJF, SOA is predicted to account for more than $50 \%$ of OA above $6 \mathrm{~km}$ altitude in winter over the United States. SOA concentrations are predicted to be larger than those of POA in the middle to high troposphere in JJA. SOA at high altitudes results from the transport of gas phase oxidation products to the upper troposphere, where colder temperatures favor condensation of the semivolatile gases into the aerosol phase.

\subsubsection{Comparisons of Predicted Organic Aerosol Concentrations with Measurements}

[17] Figure 5 compares predicted OA (POA + SOA) concentrations with IMPROVE measurements for the four seasons. Simulated and measured OA concentrations at each IMPROVE site are given in Tables 4 and 5. It is seen that the model largely reproduces the geographical distributions of OA (Figures 5a and 5b). Over the eastern United States (east of $95^{\circ} \mathrm{W}$ ), predicted OA concentrations agree closely with measurements in DJF, March-April-May (MAM), but OA levels are underpredicted in JJA and overestimated in SON (Figure 5c). Annual mean OA concentrations over the eastern United States have a mean bias (MB) of $-0.31 \mu \mathrm{g} \mathrm{m}^{-3}$ and a normalized mean bias (NMB) of $-14.7 \%$ (Table 6) as compared with the IMPROVE measurements. OA concentrations in the western United States (west of $95^{\circ} \mathrm{W}$ ) are underestimated in DJF, MAM, and SON, which correlates with the underprediction of BC concentrations in the same region (see section 3.3), suggesting that the emissions of POA over the western United States may be underestimated. Performance in predicting $\mathrm{OA}$ in the western United States improves in summer when SOA concentrations are the highest. Predicted annual mean OA concentrations in the western United states have a MB of $-0.66 \mu \mathrm{g} \mathrm{m}^{-3}$ and a NMB of $-44.8 \%$ (Table 6 ).

[18] The underestimation of OA was also found in the GEOS-CHEM simulation driven by NASA/GEOS assimilated meteorological fields [Park et al., 2003]. Assuming a $10 \%$ yield of SOA from monoterpenes and using the same POA emissions inventories as those used in this work, Park et al. [2003] reported that the predicted annual mean OA $(\mathrm{POA}+\mathrm{SOA})$ concentrations are about 25\% lower than the IMPROVE measurements for the year of 1998. The slopes of the regression lines in Figure 5 indicate that the predicted OA concentrations in this work exhibit larger low bias than those of Park et al. [2003]. The relatively strong wild fires over 2001-2003 might have contributed to our model bias; over the United States, the burned area averaged over 2001-2003 is about $8 \%$ higher than that averaged over 1991-2005 (http://www.nifc.gov/stats/fires_acres.html).

[19] Ambient measurements of OA generally do not distinguish between POA and SOA. One commonly used approach for estimating the relative contributions of POA and SOA to measured particulate OA is to use BC as a tracer [e.g., Turpin and Huntzicker, 1995; Strader et al., 1999; Lim and Turpin, 2002; Polidori et al., 2006]. This method needs to determine first $\mathrm{OA}$ to $\mathrm{BC}$ ratio based on a large data set for the times when secondary formation is unlikely, and then concentration of SOA is estimated by the ambient $\mathrm{OA}$ to $\mathrm{BC}$ ratio that is elevated above that ratio representing no SOA formation. We adopt this approach here to estimate the split of measured OA by assuming that no SOA formation occurs in the month of January and that POA exhibits the same seasonal variation as that of $\mathrm{BC}$. Doing so, we approximate the measured POA and SOA in the $i$ th month of the year by

$$
\begin{gathered}
M_{\mathrm{POA}}(i)=M_{\mathrm{OA}}(1) \times M_{\mathrm{BC}}(i) / M_{\mathrm{BC}}(1) \\
M_{\mathrm{SOA}}(i)=M_{\mathrm{OA}}(i)-M_{\mathrm{POA}}(i)
\end{gathered}
$$

where $M$ represents the IMPROVE measured value. Note that this method of splitting measured OA between POA and SOA could cause errors. SOA will be underestimated in southern part of the country where some biogenic SOA forms in winter. In urban areas, $M_{\mathrm{OA}}$ in equations (1) and (2) could include anthropogenic SOA, $M_{\mathrm{SOA}-\text { anth, thus }}$ inferred biogenic SOA would have an error of $M_{\mathrm{SOA}-\text { anth }}$ (i) $-M_{\mathrm{SOA}-\text { anth }}(1) \times M_{\mathrm{BC}}(i) / M_{\mathrm{BC}}(1)$.

[20] With these approximations, we compare in Figure 6 the seasonal variations of measured and simulated POA and SOA at 10 sites that are located within or near regions with large biogenic SOA concentrations in summer. A substantial fraction of measured OA in summer is calculated to be SOA at all sites except at Breton, Louisiana. As mentioned above, the treatment based on equations (1) and (2) can lead to an underestimate of measured SOA at Breton because SOA can form in January. Predicted ratios of SOA to OA agree well with measurements at sites such as Caney Creek in Arkansas and Great Smoky Mountains National Park in 
(a)
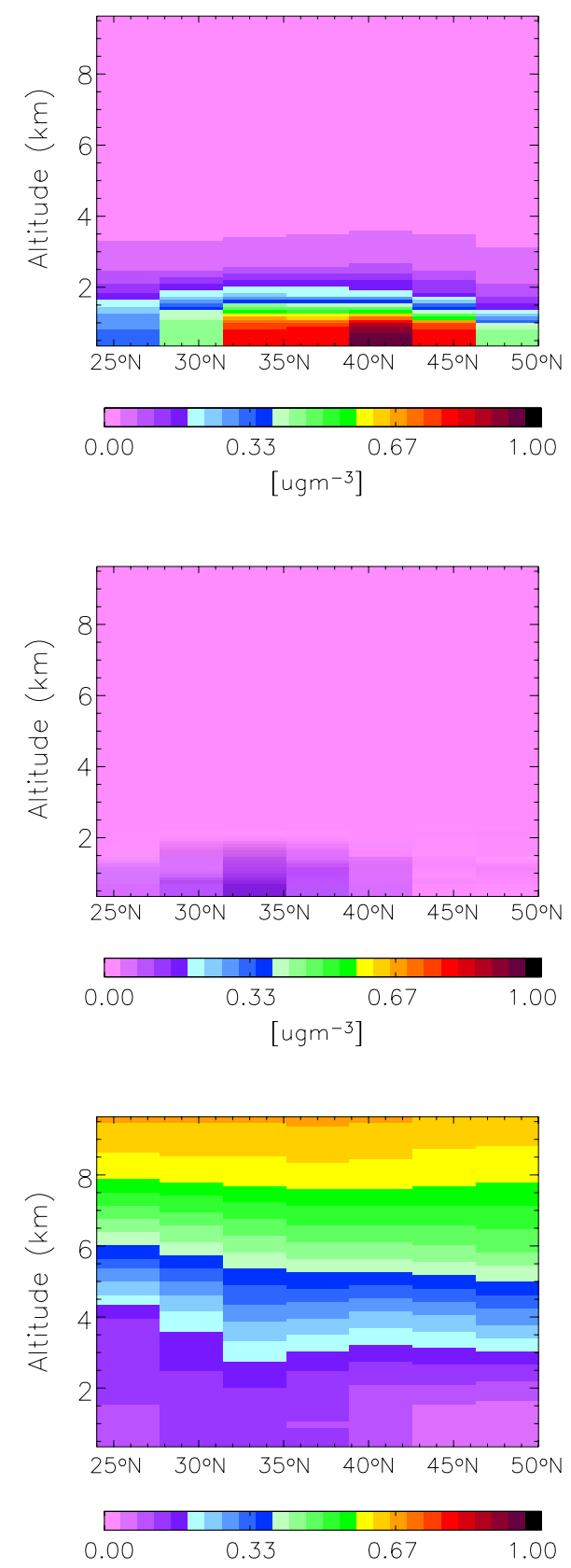

(b)
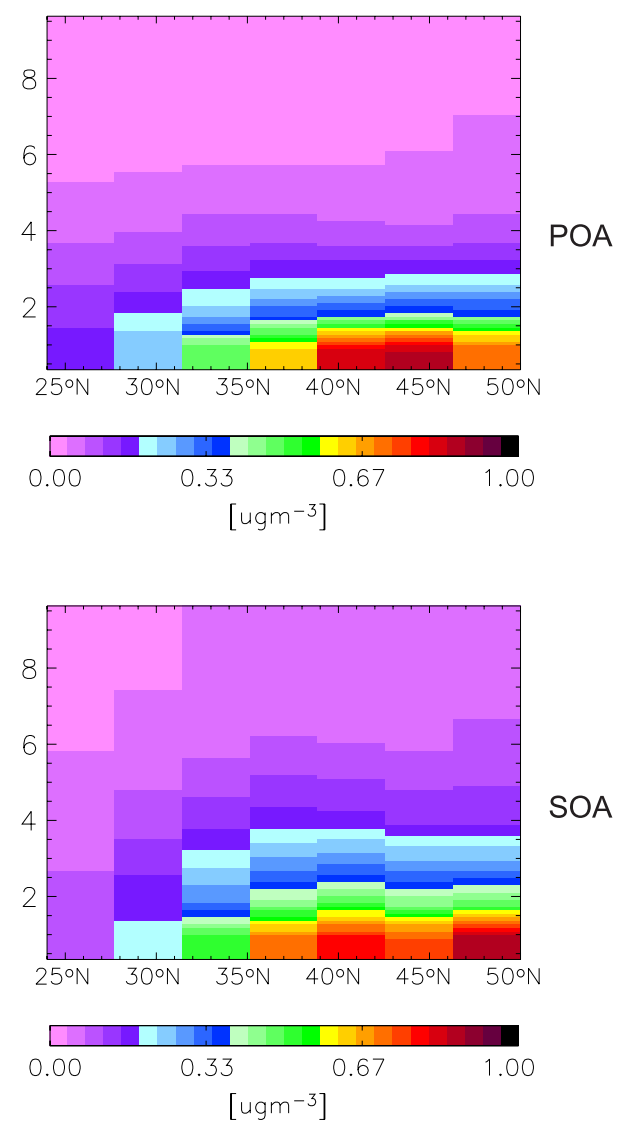

SOA

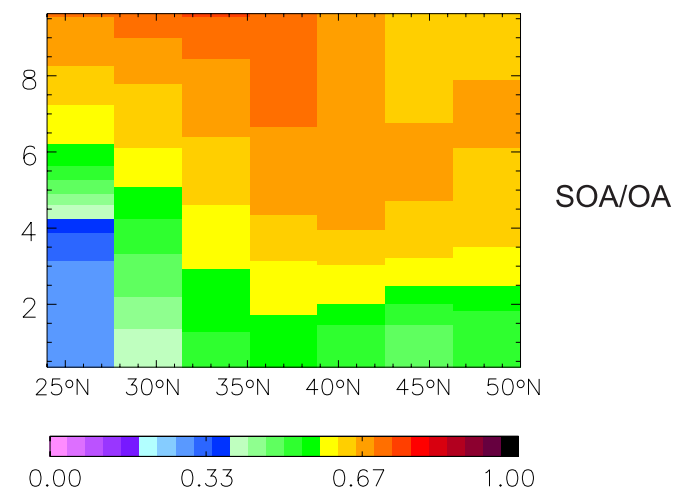

Figure 4. Altitude-latitude plots of (top) POA concentration, (middle) SOA mass, and (bottom) the ratio of SOA to OA (POA + SOA) that are zonally averaged over $130^{\circ}-65^{\circ} \mathrm{W}$ for (a) DJF and (b) JJA.

Tennessee. At the three northeastern sites (Acadia National Park in Maine, Lye Brook Wilderness in Vermont, and Washington, DC), predicted SOA to POA ratios are lower than those inferred from the measurements; we conclude that SOA is underpredicted over the northeastern United States. Comparisons at four western sites are shown in Figures $6 \mathrm{~g}-6 \mathrm{j}$. OA concentrations are underestimated at Badlands National Park in South Dakota, possibly caused by the low bias in POA emissions. At Mount Hood, Oregon, the model captures the summer POA and SOA concentrations well, but OA concentrations in winter are severely underestimated. At Mount Rainier National Park and
Snoqualamie Pass in the state of Washington, the seasonal variations of $\mathrm{OA}$ are reproduced very well, but the predicted SOA to POA ratios exceed the values calculated from measurements.

\subsubsection{Sensitivity of SOA to POA Mass}

[21] The underpredicted winter OA concentrations over the western United States (Figure 5c) suggest that the POA emissions there may be underestimated. Since SOA is assumed to condense on POA particles, and therefore that the mass of SOA depends on that of POA, inaccuracy in POA concentrations will influence predicted SOA formation. To study the sensitivity of SOA formation to POA 
(a)
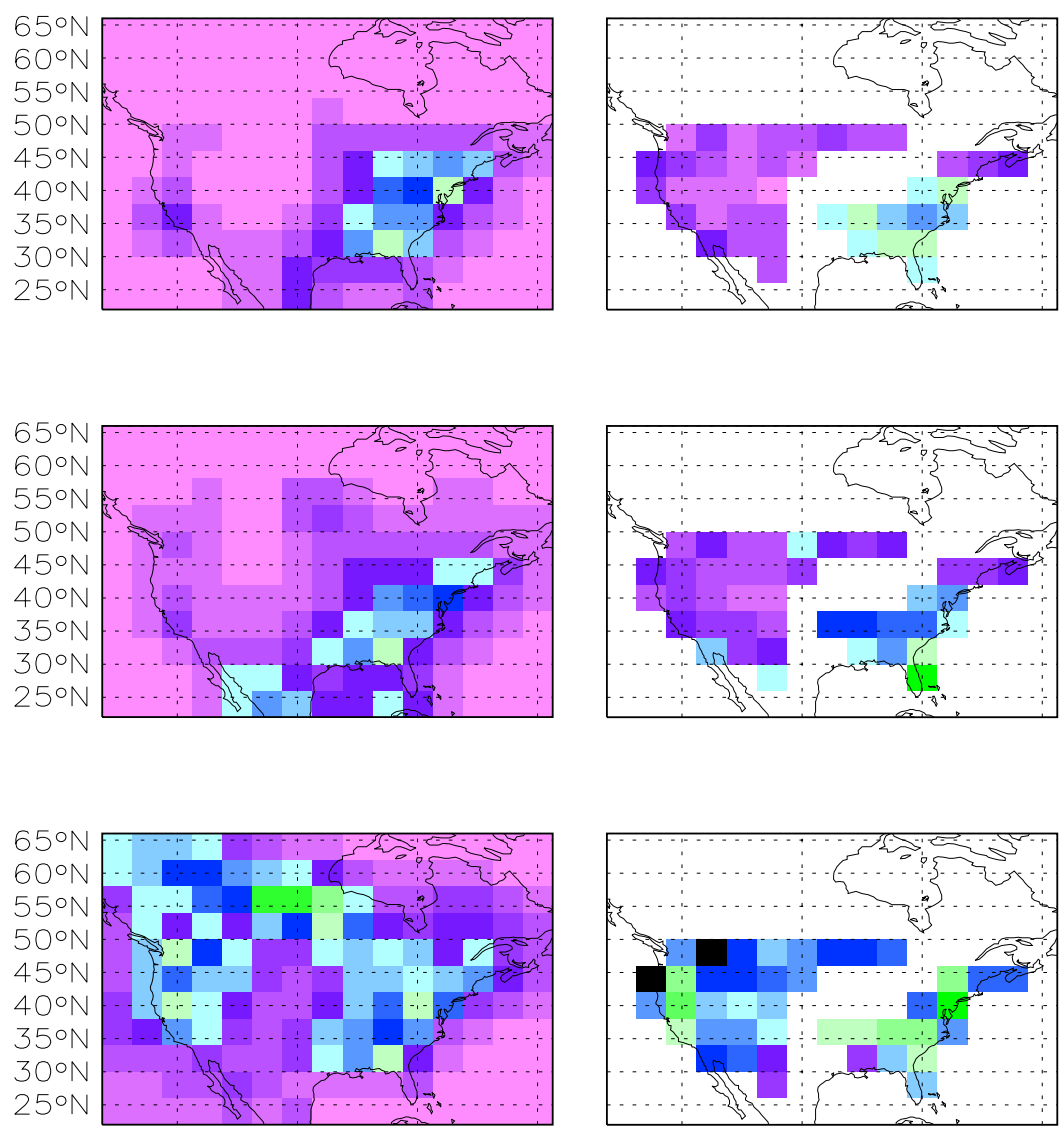

(b)
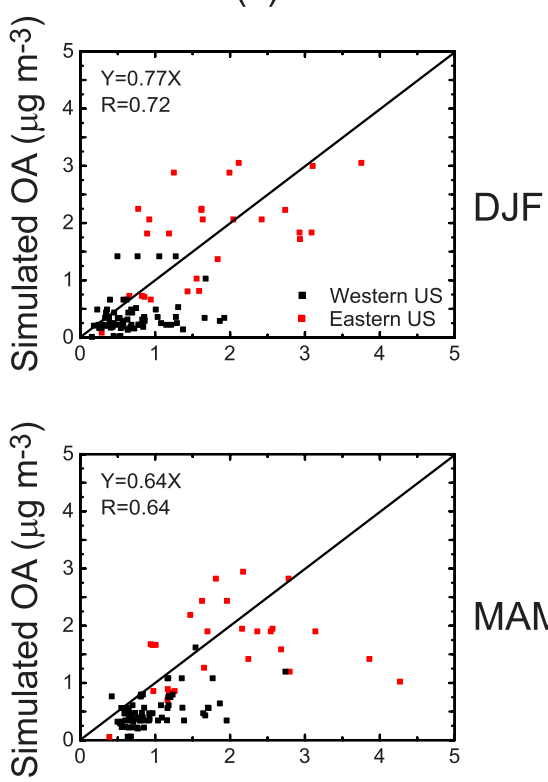

MAM

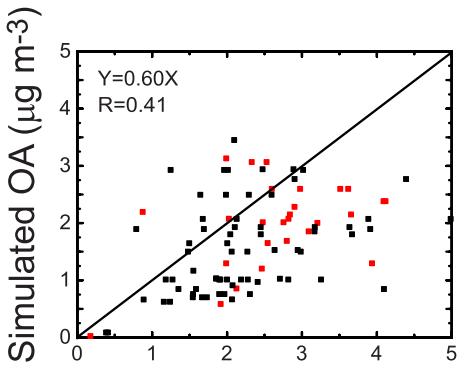

\section{JJA}
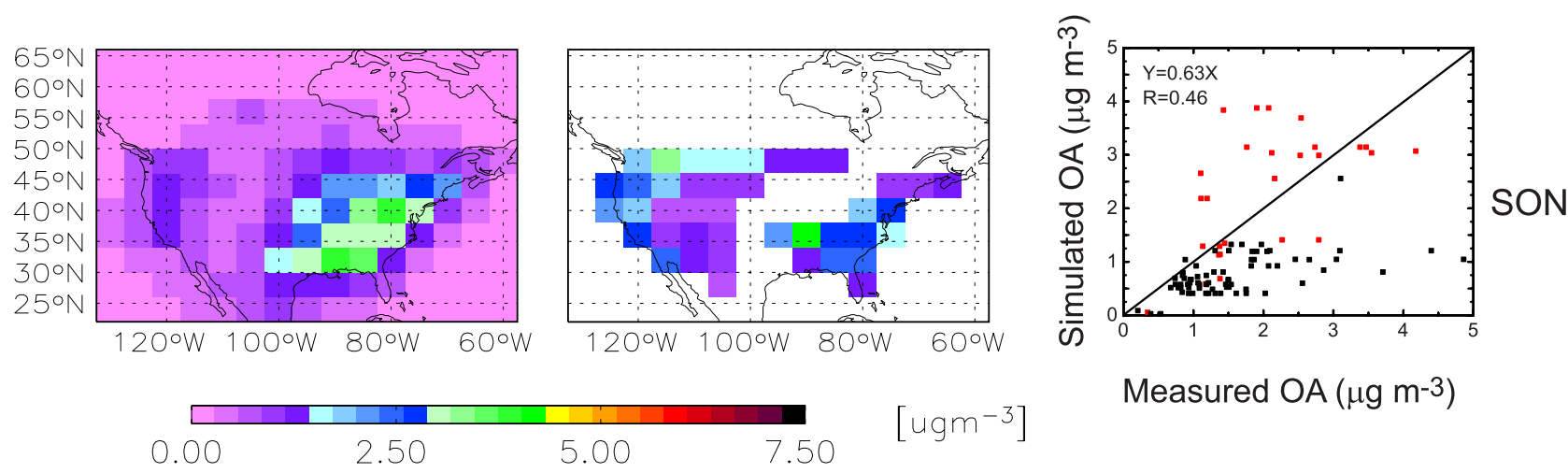

Figure 5. (a) Predicted seasonal mean surface layer $\mathrm{OA}(\mathrm{POA}+\mathrm{SOA})$ concentrations $\left(\mu \mathrm{g} \mathrm{m}^{-3}\right)$ (b) Measured seasonal mean OA concentrations at IMPROVE sites listed in Tables 4 and 5 . Measurements are averaged over years 2001-2003 and over the data points in the same grid cell. Grid cells without measurements are shown in white. (c) Simulated versus observed seasonal mean OA concentrations for all the sites listed in Tables 4 and 5. Sites in the western and eastern United States are indicated by black and red data points, respectively. The boundary between the western and eastern United States is taken as $95^{\circ} \mathrm{W}$. The solid line represents the $y=x$ relation. The regression equation and correlation coefficient $R$ for linear fit through origin are indicated.

concentrations, we assume an across the board $25 \%$ increase in POA emissions in a sensitivity simulation. With a $25 \%$ increase in POA emissions, POA concentrations throughout the United States are, as expected, about $25 \%$ percent higher than those in the baseline simulation. However, SOA formation responds nonlinearly to the increased POA.
When POA concentrations are increased by about $25 \%$, surface layer SOA formation is predicted to increase by 10 $15 \%$ in the southeastern United States, and by less than $6 \%$ over the states of Washington and Oregon, where SOA formation is the most significant in the baseline simulation. The low sensitivity of SOA concentrations to POA emis- 
Table 4. Comparisons of Simulated and Observed Particulate Matter Concentrations From the IMPROVE Database Over the Eastern United States (East of $\left.95^{\circ} \mathrm{W}\right)^{\mathrm{a}}$

\begin{tabular}{|c|c|c|c|c|c|c|c|c|c|c|c|c|}
\hline \multirow[b]{2}{*}{ Sites } & \multirow{2}{*}{$\begin{array}{c}\text { Elevation, } \\
\mathrm{m}\end{array}$} & \multirow{2}{*}{$\begin{array}{c}\text { Latitude, } \\
{ }^{\circ} \mathrm{N}\end{array}$} & \multirow{2}{*}{$\begin{array}{l}\text { Longitude, } \\
{ }^{\circ} \mathrm{W}\end{array}$} & \multicolumn{2}{|c|}{$\begin{array}{l}1.37 \times \\
{\left[\mathrm{SO}_{4}^{2-}\right]}\end{array}$} & \multicolumn{2}{|c|}{$\begin{array}{l}1.29 \times \\
{\left[\mathrm{NO}_{3}^{-}\right]}\end{array}$} & \multicolumn{2}{|c|}{$\mathrm{BC}$} & \multirow{2}{*}{$\begin{array}{l}\text { Obs. } \\
\text { OA }\end{array}$} & \multirow{2}{*}{$\begin{array}{l}\text { OA } \\
\text { Sim. } \\
\text { POA }\end{array}$} & \multirow{2}{*}{$\begin{array}{l}\text { Sim. } \\
\text { SOA }\end{array}$} \\
\hline & & & & Obs. & Sim. & Obs. & Sim. & Obs. & Sim. & & & \\
\hline Acadia National Park, ME & 150 & 44.4 & 68.3 & 2.55 & 2.38 & 0.41 & 0.28 & 0.21 & 0.44 & 1.32 & 1.57 & 0.36 \\
\hline Boundary Waters Canoe Area, MN & 523 & 47.9 & 91.5 & 1.84 & 1.42 & 0.66 & 0.65 & 0.17 & 0.18 & 1.55 & 0.88 & 0.35 \\
\hline Breton, LA & 2 & 29.1 & 89.2 & 4.30 & 2.52 & 0.61 & 0.01 & 0.3 & 0.18 & 1.35 & 1.58 & 1.04 \\
\hline Brigantine National Wildlife Refuge, NJ & 5 & 39.5 & 74.4 & 5.99 & 4.53 & 1.25 & 0.40 & 0.46 & 1.03 & 2.54 & 2.44 & 0.39 \\
\hline Chassahowitzka National Wildlife, FL & 2 & 28.7 & 82.6 & 4.12 & 2.47 & 0.53 & 0.01 & 0.46 & 0.18 & 2.45 & 2.13 & 1.06 \\
\hline Dolly Sods/Otter Creek Wilderness, WV & 1158 & 39.1 & 79.4 & 6.04 & 5.86 & 0.59 & 0.48 & 0.32 & 0.77 & 2.09 & 2.41 & 0.66 \\
\hline Everglades National Park, FL & 3 & 25.4 & 80.7 & 2.89 & 1.19 & 0.49 & 0.00 & 0.28 & 0.13 & 2.24 & 0.63 & 0.12 \\
\hline Great Gulf Wilderness, NH & 445 & 44.3 & 71.2 & 2.64 & 2.38 & 0.25 & 0.28 & 0.2 & 0.44 & 1.48 & 1.57 & 0.36 \\
\hline Great Smoky Mountains National Park, TN & 815 & 35.6 & 83.9 & 5.75 & 4.32 & 0.58 & 0.37 & 0.38 & 0.47 & 2.61 & 1.57 & 0.86 \\
\hline Isle Royale National Park, MI & 186 & 47.5 & 88.1 & 1.97 & 1.42 & 0.77 & 0.65 & 0.18 & 0.18 & 1.31 & 0.88 & 0.35 \\
\hline James River Face, VA & 299 & 37.6 & 79.5 & 6.36 & 4.16 & 0.83 & 0.13 & 0.54 & 0.51 & 2.94 & 1.64 & 0.69 \\
\hline Linville Gorge, $\mathrm{NC}$ & 986 & 36.0 & 81.9 & 5.25 & 4.16 & 0.37 & 0.13 & 0.36 & 0.51 & 2.29 & 1.64 & 0.69 \\
\hline Lye Brook Wilderness, VT & 1006 & 43.1 & 73.1 & 3.21 & 2.60 & 0.54 & 0.80 & 0.23 & 0.56 & 1.51 & 1.72 & 0.43 \\
\hline Mammoth Cave National Park, KY & 248 & 37.1 & 86.1 & 6.26 & 4.32 & 1.54 & 0.37 & 0.43 & 0.47 & 2.74 & 1.57 & 0.86 \\
\hline Mingo, $\mathrm{MO}$ & 112 & 37.0 & 90.1 & 5.21 & 3.84 & 1.72 & 0.57 & 0.48 & 0.38 & 3.17 & 1.32 & 0.85 \\
\hline Moosehorn NWR, ME & 94 & 45.1 & 67.3 & 2.49 & 1.85 & 0.36 & 0.08 & 0.26 & 0.18 & 1.61 & 0.65 & 0.25 \\
\hline Okefenokee National Wildlife Refuge, GA & 49 & 30.7 & 82.1 & 4.48 & 2.92 & 0.49 & 0.03 & 0.4 & 0.27 & 3.42 & 1.11 & 0.38 \\
\hline Cape Romain National Wildlife Refuge, SC & 3 & 33.0 & 79.7 & 4.60 & 2.92 & 0.52 & 0.03 & 0.35 & 0.27 & 2.36 & 1.11 & 0.38 \\
\hline Seney, MI & 216 & 46.3 & 85.9 & 2.69 & 1.88 & 1.06 & 0.40 & 0.2 & 0.2 & 1.48 & 0.80 & 0.25 \\
\hline Shenandoah National Park, VA & 1098 & 38.5 & 78.4 & 5.99 & 5.86 & 0.99 & 0.48 & 0.33 & 0.77 & 1.83 & 2.41 & 0.66 \\
\hline Shining Rock Wilderness, NC & 1621 & 35.4 & 82.8 & 4.48 & 4.32 & 0.34 & 0.37 & 0.21 & 0.47 & 1.75 & 1.57 & 0.86 \\
\hline Sipsey Wilderness, AL & 279 & 34.3 & 87.3 & 5.71 & 4.32 & 0.99 & 0.37 & 0.45 & 0.47 & 3.11 & 1.57 & 0.86 \\
\hline Swanquarter, NC & 2 & 35.5 & 76.2 & 4.52 & 3.27 & 0.55 & 0.05 & 0.25 & 0.35 & 1.76 & 0.98 & 0.23 \\
\hline Upper Buffalo Wilderness, AR & 723 & 35.8 & 93.2 & 3.75 & 2.64 & 1.12 & 0.84 & 0.29 & 0.27 & 2.40 & 0.95 & 0.71 \\
\hline Virgin Islands National Park, VI & 64 & 18.3 & 64.8 & 1.05 & 2.03 & 0.18 & 0.01 & 0.09 & 0.03 & 0.30 & 0.05 & 0.00 \\
\hline Voyageurs National Park 2, MN & 429 & 48.4 & 92.8 & 1.59 & 1.25 & 0.76 & 0.86 & 0.17 & 0.17 & 1.58 & 0.80 & 0.29 \\
\hline Washington, DC & 16 & 38.9 & 77.0 & 6.96 & 4.53 & 1.88 & 0.40 & 0.83 & 1.03 & 3.54 & 2.44 & 0.39 \\
\hline
\end{tabular}

${ }^{\mathrm{a}}$ Concentrations are in $\mu \mathrm{g} \mathrm{m}^{-3}$. Obs., observed; Sim., simulated.

sions in the western United States suggests that the underprediction of OA, at least in part, comes from an underestimation of POA emissions. With SOA formation increased in the lower layers in the sensitivity simulation, less gas phase oxidation products are available to be transported to the upper troposphere, leading to reduced SOA formation in the middle to upper troposphere. This is reflected in the changes of global burdens of POA and SOA; compared with the baseline simulation, a $25 \%$ increase in POA emissions in the sensitivity study changes the global POA burden by $+24 \%$ but increases the global SOA burden by less than $1 \%$

\subsubsection{Contributions of Different Parent Hydrocarbon} Classes to SOA Formation

[22] Figure 7 presents surface layer annual mean fraction of total SOA mass formed from the oxidation of each of hydrocarbon classes I-III, class IV, class V, and isoprene. SOA formation from classes I-III is predicted to account for $60-75 \%$ of total SOA over the northwestern and northeastern United States where emissions of monoterpenes and ORVOCs are larger than those of isoprene. Isoprene is predicted to contribute about $60-75 \%$ of SOA in the southwestern United States. Over the southeast United States, hydrocarbon classes I-III and isoprene are both the major sources of SOA; classes I-III and isoprene account for $35-40 \%$ and $30-35 \%$ of SOA formation there, respectively. Each of hydrocarbon classes IV and V is predicted to contribute less than $20 \%$ of SOA formation throughout the United States.

[23] Table 7 lists the contribution of each class of reactive hydrocarbons to the predicted SOA burden over the United
States and, for comparison, to the global SOA burden. Isoprene has the largest contribution of $49.5 \%$ to SOA burden over the United States, followed by a $39.5 \%$ contribution from hydrocarbon classes I-III, 5.7\% from class V, and $5.3 \%$ from class IV. Oxidation products of isoprene are transported to higher altitudes or more remote sites than those of other reactive hydrocarbons [Henze and Seinfeld, 2006]. As a result, SOA from isoprene can exist at high latitudes and remote sites, which explains the proportionately larger predicted contribution (58.2\%) of SOA from isoprene to the global SOA burden.

\subsection{Predicted Inorganic Aerosols and Fine PM Mass}

[24] It is important to evaluate present-day climatological predictions of sulfate, nitrate, $\mathrm{BC}$, and $\mathrm{PM}_{2.5}$ mass concentrations, as these will play an important role under future climate conditions. Since the IMPROVE data do not include direct measurements of ammonium, $\mathrm{PM}_{2.5}$ mass is calculated as [Malm et al., 1994]

$$
\begin{aligned}
{\left[\mathrm{PM}_{2.5}\right]=} & 1.37 \times\left[\mathrm{SO}_{4}^{2-}\right]+1.29 \times\left[\mathrm{NO}_{3}^{-}\right]+[\mathrm{BC}]+[\mathrm{POA}] \\
& +[\mathrm{SOA}]
\end{aligned}
$$

where 1.37 and 1.29 are factors used for converting the IMPROVE measured $\mathrm{SO}_{4}^{2-}$ and $\mathrm{NO}_{3}^{-}$ions to concentrations of ammonium sulfate and ammonium nitrate, respectively. Mineral dust aerosol is not considered here, so there is an inherent underestimate of $\mathrm{PM}_{2.5}$ mass over the western United States where mineral dust is an important aerosol component. 
Table 5. Comparisons of Simulated and Observed Particulate Matter Concentrations From the IMPROVE Database Over the Western United States (West of $95^{\circ} \mathrm{W}$ ) ${ }^{\mathrm{a}}$

\begin{tabular}{|c|c|c|c|c|c|c|c|c|c|c|c|c|}
\hline \multirow[b]{2}{*}{ Sites } & \multirow{2}{*}{$\begin{array}{c}\text { Elevation, } \\
\mathrm{m}\end{array}$} & \multirow{2}{*}{$\begin{array}{c}\text { Latitude, } \\
{ }^{\circ} \mathrm{N}\end{array}$} & \multirow{2}{*}{$\begin{array}{c}\text { Longitude, } \\
{ }^{\circ} \mathrm{W}\end{array}$} & \multicolumn{2}{|c|}{$\begin{array}{c}1.37 \times \\
{\left[\mathrm{SO}_{4}{ }^{2-}\right]}\end{array}$} & \multicolumn{2}{|c|}{$\begin{array}{c}1.29 \times \\
{\left[\mathrm{NO}_{3}{ }^{-}\right]}\end{array}$} & \multicolumn{2}{|c|}{$\mathrm{BC}$} & & $\begin{array}{l}\text { OA } \\
\text { Sim. }\end{array}$ & \\
\hline & & & & Obs. & Sim. & Obs. & Sim. & Obs. & Sim. & $\mathrm{OA}$ & & SOA \\
\hline Agua Tibia, CA & 507 & 33.5 & 117.0 & 2.64 & 1.42 & 2.31 & 2.58 & 0.44 & 0.19 & 2.11 & 0.53 & 0.17 \\
\hline Badlands National Park, SD & 736 & 43.7 & 101.9 & 1.38 & 0.90 & 0.46 & 0.19 & 0.14 & 0.09 & 1.15 & 0.29 & 0.20 \\
\hline Mount Baldy, AZ & 2513 & 34.1 & 109.4 & 0.92 & 0.89 & 0.22 & 1.25 & 0.16 & 0.07 & 1.35 & 0.22 & 0.28 \\
\hline Bandelier National Monument, NM & 1987 & 35.8 & 106.3 & 0.97 & 0.71 & 0.27 & 0.35 & 0.15 & 0.08 & 1.14 & 0.25 & 0.24 \\
\hline Big Bend National Park, TX & 1075 & 29.3 & 103.2 & 2.82 & 0.96 & 0.30 & 0.36 & 0.13 & 0.14 & 1.00 & 0.56 & 0.34 \\
\hline Bliss State Park (TRPA), CA & 2116 & 39.0 & 120.1 & 0.62 & 0.52 & 0.23 & 1.20 & 0.15 & 0.22 & 1.37 & 0.75 & 0.68 \\
\hline Bryce Canyon National Park, UT & 2477 & 37.6 & 112.2 & 0.73 & 0.89 & 0.31 & 1.25 & 0.17 & 0.07 & 1.50 & 0.22 & 0.28 \\
\hline Bridger Wilderness, WY & 2607 & 43.0 & 109.8 & 0.63 & 0.36 & 0.19 & 0.75 & 0.1 & 0.07 & 0.95 & 0.42 & 0.30 \\
\hline Brooklyn Lake, WY & 3196 & 41.4 & 106.2 & 0.77 & 0.53 & 0.23 & 0.46 & 0.08 & 0.09 & 0.83 & 0.23 & 0.22 \\
\hline Cabinet Mountains, MT & 1434 & 48.0 & 115.7 & 0.63 & 0.27 & 0.19 & 0.21 & 0.15 & 0.09 & 1.71 & 0.52 & 0.62 \\
\hline Caney Creek, AR & 690 & 34.5 & 94.1 & 4.26 & 2.64 & 1.12 & 0.84 & 0.32 & 0.27 & 2.67 & 0.95 & 0.71 \\
\hline Canyonlands National Park, UT & 1799 & 38.5 & 109.8 & 0.81 & 0.48 & 0.26 & 1.29 & 0.1 & 0.08 & 0.84 & 0.24 & 0.28 \\
\hline Chiricahua National Monument, AZ & 1570 & 32.0 & 109.4 & 1.30 & 1.75 & 0.23 & 0.75 & 0.11 & 0.12 & 0.84 & 0.37 & 0.23 \\
\hline Columbia River Gorge, WA & 201 & 45.7 & 121.0 & 1.18 & 0.33 & 1.24 & 0.31 & 0.32 & 0.13 & 1.98 & 0.57 & 0.58 \\
\hline Crater Lake National Park, OR & 1963 & 42.9 & 122.1 & 0.45 & 0.33 & 0.19 & 0.31 & 0.28 & 0.13 & 2.64 & 0.57 & 0.58 \\
\hline Craters of the Moon NM(US DOE), ID & 1817 & 43.5 & 113.6 & 0.59 & 0.32 & 0.53 & 0.52 & 0.11 & 0.09 & 1.06 & 0.46 & 0.41 \\
\hline Denali National Park, AK & 658 & 63.7 & 149.0 & 0.41 & 0.11 & 0.05 & 0.01 & 0.07 & 0.04 & 0.78 & 0.80 & 0.10 \\
\hline Death Valley Monument, CA & 125 & 36.5 & 116.8 & 1.08 & 0.86 & 0.32 & 2.57 & 0.12 & 0.17 & 1.00 & 0.48 & 0.29 \\
\hline Dome Lands Wilderness, CA & 925 & 35.7 & 118.1 & 1.45 & 0.93 & 1.35 & 2.35 & 0.25 & 0.52 & 2.12 & 1.17 & 0.28 \\
\hline Gates of the Mountains, MT & 2392 & 46.8 & 111.7 & 0.52 & 0.29 & 0.19 & 0.31 & 0.1 & 0.06 & 1.33 & 0.31 & 0.30 \\
\hline Gila Wilderness, NM & 1776 & 33.2 & 108.2 & 1.00 & 1.75 & 0.15 & 0.75 & 0.19 & 0.12 & 1.72 & 0.37 & 0.23 \\
\hline Glacier National Park, MT & 979 & 48.5 & 114.0 & 0.84 & 0.27 & 0.36 & 0.21 & 0.57 & 0.09 & .97 & 0.52 & 0.62 \\
\hline Great Basin National Park, NV & 2068 & 39.0 & 114.2 & 0.60 & 0.45 & 0.18 & 1.25 & 0.12 & 0.1 & 0.92 & 0.36 & 0.40 \\
\hline Hance Camp at Grand Canyon NP, AZ & 2267 & 36.0 & 112.0 & 0.79 & 0.89 & 0.25 & 1.25 & 0.11 & 0.07 & 0.83 & 0.22 & 0.28 \\
\hline Great Sand Dunes National Monument, $\mathrm{CO}$ & 2504 & 37.7 & 105.5 & 0.77 & 0.71 & 0.23 & 0.35 & 0.11 & 0.08 & 1.05 & 0.25 & 0.24 \\
\hline Guadalupe Mountains National Park, TX & 1674 & 31.8 & 104.8 & 1.63 & 1.07 & 0.37 & 0.39 & 0.09 & 0.11 & 0.96 & 0.33 & 0.28 \\
\hline Haleakala National Park, HI & 1158 & 20.8 & 156.3 & 1.29 & 1.23 & 0.27 & 0.04 & 0.08 & 0.01 & 0.47 & 0.04 & 0.01 \\
\hline Hawaii Volcanoes National Park, HI & 1204 & 19.4 & 155.3 & 2.85 & 1.23 & 0.12 & 0.04 & 0.04 & 0.01 & 0.53 & 0.04 & 0.01 \\
\hline Hells Canyon, OR & 625 & 45.0 & 116.8 & 0.63 & 0.32 & 0.45 & 0.52 & 0.16 & 0.09 & 1.64 & 0.46 & 0.41 \\
\hline Ike's Backbone, AZ & 1303 & 34.3 & 111.7 & 1.11 & 0.89 & 0.52 & 1.25 & 0.15 & 0.07 & 1.02 & 0.22 & 0.28 \\
\hline Jarbidge Wilderness, NV & 1882 & 41.9 & 115.4 & 0.49 & 0.45 & 0.15 & 1.25 & 0.08 & 0.1 & 0.94 & 0.36 & 0.40 \\
\hline Joshua Tree, CA & 1228 & 34.1 & 116.4 & 1.40 & 0.86 & 1.61 & 2.57 & 0.23 & 0.17 & 1.35 & 0.48 & 0.29 \\
\hline Kalmiopsis, OR & 90 & 42.6 & 124.1 & 0.66 & 0.45 & 0.18 & 0.06 & 0.3 & 0.11 & 3.21 & 0.47 & 0.34 \\
\hline Lava Beds, CA & 1469 & 41.7 & 121.5 & 0.53 & 0.52 & 0.21 & 1.20 & 0.2 & 0.22 & 2.28 & 0.75 & 0.68 \\
\hline Lassen Volcanic National Park, CA & 1755 & 40.5 & 121.6 & 0.58 & 0.52 & 0.25 & 1.20 & 0.15 & 0.22 & 1.45 & 0.75 & 0.68 \\
\hline Lostwood, ND & 692 & 48.6 & 102.4 & 1.62 & 0.99 & 1.07 & 0.36 & 0.17 & 0.09 & 1.52 & 0.38 & 0.18 \\
\hline Medicine Lake, MT & 605 & 48.5 & 104.5 & 1.27 & 0.41 & 0.80 & 0.21 & 0.13 & 0.06 & 1.14 & 0.26 & 0.21 \\
\hline Jerde National Park, CO & 2177 & 37.2 & 108.5 & 0.85 & 0.89 & 0.26 & 1.25 & 0.12 & 0.07 & 1.07 & 0.22 & 0.28 \\
\hline Mount Hood, OR & 1341 & 45.3 & 121.8 & 0.55 & 0.33 & 0.25 & 0.31 & 0.11 & 0.13 & 0.96 & 0.57 & 0.58 \\
\hline Monture, MT & 1293 & 47.1 & 113.2 & 0.55 & 0.27 & 0.15 & 0.21 & 0.2 & 0.09 & 2.31 & 0.52 & 0.62 \\
\hline Mount Rainier National Park, WA & 427 & 46.8 & 122.1 & 0.93 & 0.32 & 0.19 & 0.18 & 0.26 & 0.14 & 1.52 & 0.60 & 0.70 \\
\hline Mount Zirkel Wilderness, CO & 3243 & 40.5 & 106.7 & 0.70 & 0.53 & 0.22 & 0.46 & 0.09 & 0.09 & 0.91 & 0.23 & 0.22 \\
\hline Absaroka, WY & 2480 & 44.7 & 109.4 & 0.59 & 0.36 & 0.18 & 0.75 & 0.09 & 0.07 & 1.07 & 0.42 & 0.30 \\
\hline Pasayten, WA & 1634 & 48.4 & 119.9 & 0.47 & 0.32 & 0.15 & 0.18 & 0.16 & 0.14 & 1.71 & 0.60 & 0.70 \\
\hline Petrified Forest National Park, AZ & 1767 & 35.1 & 109.8 & 1.01 & 0.89 & 0.34 & 1.25 & 0.24 & 0.07 & 1.50 & 0.22 & 0.28 \\
\hline Pinnacles National Monument, CA & 317 & 36.5 & 121.2 & 1.25 & 0.93 & 0.94 & 2.35 & 0.26 & 0.52 & 1.55 & 1.17 & 0.28 \\
\hline Point Reyes National Seashore, CA & 85 & 38.1 & 122.9 & 1.59 & 0.47 & 1.28 & 0.09 & 0.12 & 0.13 & 1.00 & 0.54 & 0.32 \\
\hline San Rafael, CA & 953 & 34.7 & 120.0 & 1.49 & 0.93 & 0.86 & 2.35 & 0.19 & 0.52 & 1.55 & 1.17 & 0.28 \\
\hline Redwood National Park, CA & 245 & 41.6 & 124.1 & 0.85 & 0.47 & 0.34 & 0.09 & 0.1 & 0.13 & 1.17 & 0.54 & 0.32 \\
\hline Rocky Mountain National Park, CO & 2755 & 40.3 & 105.5 & 0.85 & 0.53 & 0.45 & 0.46 & 0.13 & 0.09 & 1.07 & 0.23 & 0.22 \\
\hline Salt Creek, NM & 1077 & 33.5 & 104.4 & 2.21 & 1.07 & 0.89 & 0.39 & 0.16 & 0.11 & 1.11 & 0.33 & 0.28 \\
\hline San Gorgonio Wilderness, CA & 1705 & 34.2 & 116.9 & 1.36 & 0.86 & 2.88 & 2.57 & 0.31 & 0.17 & 1.70 & 0.48 & 0.29 \\
\hline San Pedro Parks, NM & 2919 & 36.0 & 106.8 & 0.82 & 0.71 & 0.19 & 0.35 & 0.1 & 0.08 & 0.89 & 0.25 & 0.24 \\
\hline Sawtooth National Forest, ID & 1980 & 44.2 & 114.9 & 0.44 & 0.32 & 0.09 & 0.52 & 0.19 & 0.09 & 1.84 & 0.46 & 0.41 \\
\hline Sierra Ancha, AZ & 1595 & 34.1 & 110.9 & 1.11 & 0.89 & 0.41 & 1.25 & 0.18 & 0.07 & 1.61 & 0.22 & 0.28 \\
\hline Snoqualamie Pass, Snoqualamie N.F, WA & 1160 & 47.4 & 121.4 & 0.84 & 0.32 & 0.39 & 0.18 & 0.23 & 0.14 & 1.32 & 0.60 & 0.70 \\
\hline Starkey, OR & 1258 & 45.2 & 118.5 & 0.64 & 0.33 & 0.44 & 0.31 & 0.26 & 0.13 & 2.58 & 0.57 & 0.58 \\
\hline Sula (Selway Bitteroot Wilderness), MT & 1903 & 45.9 & 114.0 & 0.48 & 0.32 & 0.14 & 0.52 & 0.14 & 0.09 & 1.72 & 0.46 & 0.41 \\
\hline Sycamore Canyon, AZ & 2040 & 35.1 & 112.0 & 0.92 & 0.89 & 0.35 & 1.25 & 0.25 & 0.07 & 1.62 & 0.22 & 0.28 \\
\hline Theodore Roosevelt, ND & 853 & 46.9 & 103.4 & 1.33 & 0.41 & 0.65 & 0.21 & 0.17 & 0.06 & 1.29 & 0.26 & 0.21 \\
\hline Three Sisters Wilderness, OR & 885 & 44.3 & 122.0 & 0.63 & 0.33 & 0.14 & 0.31 & 0.15 & 0.13 & 1.43 & 0.57 & 0.58 \\
\hline Tonto National Monument, AZ & 786 & 33.6 & 111.1 & 1.32 & 1.75 & 0.44 & 0.75 & 0.2 & 0.12 & 1.29 & 0.37 & 0.23 \\
\hline Trinity, CA & 1007 & 40.8 & 122.8 & 0.55 & 0.47 & 0.26 & 0.09 & 0.21 & 0.13 & 2.39 & 0.54 & 0.32 \\
\hline UL Bend, MT & 893 & 47.6 & 108.7 & 0.88 & 0.29 & 0.39 & 0.31 & 0.13 & 0.06 & 1.35 & 0.31 & 0.30 \\
\hline Weminuche Wilderness, $\mathrm{CO}$ & 2765 & 37.7 & 107.8 & 0.66 & 0.89 & 0.14 & 1.25 & 0.14 & 0.07 & 0.98 & 0.22 & 0.28 \\
\hline White Pass, WA & 1830 & 46.6 & 121.4 & 0.49 & 0.32 & 0.13 & 0.18 & 0.07 & 0.14 & 0.69 & 0.60 & 0.70 \\
\hline White River National Forest, $\mathrm{CO}$ & 3418 & 39.2 & 106.8 & 0.59 & 0.53 & 0.18 & 0.46 & 0.1 & 0.09 & 0.78 & 0.23 & 0.22 \\
\hline Wind Cave, SD & 1300 & 43.6 & 103.5 & 1.08 & 0.44 & 0.43 & 0.40 & 0.14 & 0.06 & 1.22 & 0.22 & 0.23 \\
\hline Yellowstone National Park 2, WY & 2425 & 44.6 & 110.4 & 0.60 & 0.36 & 0.25 & 0.75 & 0.13 & 0.07 & 1.54 & 0.42 & 0.30 \\
\hline
\end{tabular}


Table 5. (continued)

\begin{tabular}{|c|c|c|c|c|c|c|c|c|c|c|c|c|}
\hline \multirow[b]{2}{*}{ Sites } & \multirow{2}{*}{$\begin{array}{c}\text { Elevation, } \\
\mathrm{m}\end{array}$} & \multirow{2}{*}{$\begin{array}{c}\text { Latitude, } \\
{ }^{\circ} \mathrm{N}\end{array}$} & \multirow{2}{*}{$\begin{array}{c}\text { Longitude, } \\
{ }^{\circ} \mathrm{W}\end{array}$} & \multicolumn{2}{|c|}{$\begin{array}{c}1.37 \times \\
{\left[\mathrm{SO}_{4}{ }^{2-}\right]} \\
\end{array}$} & \multicolumn{2}{|c|}{$\begin{array}{c}1.29 \times \\
{\left[\mathrm{NO}_{3}^{-}\right]} \\
\end{array}$} & \multicolumn{2}{|c|}{$\mathrm{BC}$} & \multirow{2}{*}{$\begin{array}{c}\text { Obs. } \\
\text { OA }\end{array}$} & \multirow{2}{*}{$\begin{array}{l}\text { OA } \\
\text { Sim. } \\
\text { POA }\end{array}$} & \multirow{2}{*}{$\begin{array}{l}\text { Sim } \\
\text { SOA }\end{array}$} \\
\hline & & & & Obs. & Sim. & Obs. & Sim. & Obs. & Sim. & & & \\
\hline Yosemite National Park, CA & 1615 & 37.7 & 119.7 & 0.89 & 0.93 & 0.49 & 2.35 & 0.29 & 0.52 & 3.04 & 1.17 & 0.28 \\
\hline Zion, UT & 1545 & 37.5 & 113.2 & 0.89 & 0.86 & 0.55 & 2.57 & 0.18 & 0.17 & 0.87 & 0.48 & 0.29 \\
\hline
\end{tabular}

${ }^{\mathrm{a}}$ Concentrations are in $\mu \mathrm{g} \mathrm{m}^{-3}$. Obs., observed; Sim., simulated.

[25] Figure 8 shows simulated and observed annual mean distributions of sulfate $\left(1.37 \times\left[\mathrm{SO}_{4}^{2-}\right]\right)$, nitrate $(1.29 \times$ $\left.\left[\mathrm{NO}_{3}^{-}\right]\right), \mathrm{BC}$, and $\mathrm{PM}_{2.5}$ mass concentrations, as well as scatterplots of simulated versus observed annual mean concentrations for these species and $\mathrm{PM}_{2.5}$. The spatial pattern of sulfate is reproduced well with a correlation coefficient $\mathrm{R}$ of 0.95 , but sulfate concentrations are generally underpredicted, with a NMB of $-32.4 \%$ in the western and of $-21.6 \%$ in the eastern United States (Table 6). Predicted nitrate concentrations in the western United States are on average $75 \%$ higher than the measurements with a few cases up to an order of magnitude higher, while nitrate in the eastern United States is underpredicted with a NMB of $-54.4 \%$ (Table 6 ). Nitrate aerosol concentrations are strongly dependent upon factors such as $\mathrm{O}_{3}-\mathrm{NO}_{\mathrm{x}}$ chemistry, heterogeneous reactions, thermodynamic interaction with sulfate and ammonium, and emissions of $\mathrm{NO}_{\mathrm{x}}$, sulfur, and ammonia [Adams et al., 1999; Liao et al., 2003, 2004]. The high degree of nonlinearity inherent in the coupling of these processes precludes any simple assessment of the discrepancy between modeled and observed nitrate concentrations. Further more, bias intrinsic in the IMPROVE nitrate measurements could also influence the evaluation of the model performance. Ames and Malm [2001] compared the measurements from the IMPROVE network with those from the Clean Air Status and Trends Network (CASTNET) and reported that, while observed differences between sulfate concentrations reported by the two monitoring networks are generally small, nitrate concentrations from the CASTNET are $40 \%$ higher in the western United States and 56\% higher in the interior desert/mountain region. They found that higher $\mathrm{NO}_{3}^{-}$concentrations observed by the CASTNET in the western United States resulted from the enhanced coarse-particle $\mathrm{NO}_{3}^{-}$collection efficiency in the non-sizeselective CASTNET sampler. As mentioned earlier, this study does not include the simulation of mineral dust and hence no heterogeneous reactions on dust particles. If we accounted for mineral dust uptake of gas phase $\mathrm{HNO}_{3}$, fine nitrate concentrations would have been reduced largely [Liao and Seinfeld, 2005] to agree more closely with the fine nitrate mass measured by the IMPROVE network.

[26] The NMB of predicted BC is $-24.2 \%$ in the western and $+28.7 \%$ in the eastern United States (Table 6). Over the western United States, the underprediction of BC agrees with that of predicted POA, indicating a possible low bias in emissions of POA and BC. The model's performance in predicting mass concentrations of $\mathrm{PM}_{2.5}$ in the eastern United States is governed by that of sulfate aerosol. In the western United States, the model's low biases in predicting sulfate and $\mathrm{BC}$ are offset by the high bias in simulating nitrate. As a result, the model underpredicts $\mathrm{PM}_{2.5}$ with a NMB of about $20 \%$ in both the western and eastern United States (Table 6). The regression line for $\mathrm{PM}_{2.5}$ has a slope of 0.77 and a correlation coefficient of 0.84 (Figure 8c). Note again that the absence of mineral dust in this study may have contributed to the underprediction of $\mathrm{PM}_{2.5}$ mass in the western United States.

[27] Comparisons of measured versus predicted seasonal variations of sulfate, nitrate, $\mathrm{BC}$, and $\mathrm{PM}_{2.5}$ are shown in Figure 5. At most sites, measurements and model predictions exhibit maximum sulfate concentrations in summer and maximum nitrate levels in winter. Peak sulfate concentrations in JJA at Lye Brook Wilderness in Vermont and Washington D. C. are underestimated. At the southeastern sites of Caney Creek and Great Smoky Mountains, peak sulfate concentrations are predicted to occur in SON, which may be caused by uncertainties in the seasonal variation of emissions. At the western sites, seasonal variations are reproduced well, but sulfate concentrations are generally underestimated. Predicted nitrate concentrations agree fairly well with measurements at most sites; concentrations at Washington D. C. are underestimated and the predicted seasonal variation at Mount Hood is out of phase with that of measurements.

[28] Since the GISS GCM/GEOS-CHEM interface is built for predicting the effect of future climate change on

Table 6. Summary Statistics for Evaluation of Concentrations of Aerosol Species ${ }^{\mathrm{a}}$

\begin{tabular}{|c|c|c|c|c|c|c|}
\hline \multirow[b]{2}{*}{ Species } & \multicolumn{2}{|c|}{ Western United States } & \multicolumn{2}{|c|}{ Eastern United States } & \multicolumn{2}{|c|}{ United States } \\
\hline & $\mathrm{MB}, \mu \mathrm{g} \mathrm{m}^{-3}$ & NMB & $\mathrm{MB}, \mu \mathrm{g} \mathrm{m}^{-3}$ & NMB & $\mathrm{MB}, \mu \mathrm{g} \mathrm{m}^{-3}$ & NMB \\
\hline $1.37 \times\left[\mathrm{SO}_{4}^{2-}\right]$ & -0.33 & $-32.4 \%$ & -0.90 & $-21.6 \%$ & -0.49 & $-25.9 \%$ \\
\hline $1.29 \times\left[\mathrm{NO}_{3}^{-}\right]$ & 0.35 & $+75.6 \%$ & -0.41 & $-54.4 \%$ & 0.14 & $+25.0 \%$ \\
\hline $\mathrm{BC}$ & -0.04 & $-24.2 \%$ & 0.09 & $+28.7 \%$ & -0.004 & $-1.9 \%$ \\
\hline $\mathrm{OA}$ & -0.66 & $-44.8 \%$ & -0.31 & $-14.7 \%$ & -0.56 & $-34.2 \%$ \\
\hline $\mathrm{PM}_{2.5}$ & -0.68 & $-21.8 \%$ & -1.38 & $-18.8 \%$ & -0.87 & $-20.4 \%$ \\
\hline
\end{tabular}

${ }^{\mathrm{a}}$ The boundary between the western and eastern United States is taken as $95^{\circ} \mathrm{W}$. Mean bias $(\mathrm{MB})=\frac{1}{N} \sum_{i=1}^{N}\left(P_{i}-O_{i}\right)$, and normalized mean bias $(\mathrm{NMB})=$ $100 \% \times \sum_{i=1}^{N}\left(P_{i}-O_{i}\right) / \sum_{i=1}^{N} O_{i}$, where $P_{i}$ is the model prediction at station $i, O_{i}$ is the observed value at station $i$, and $N$ is the number of model-observed pairs for all valid monitoring data. 
(a) Acadia National Park, ME

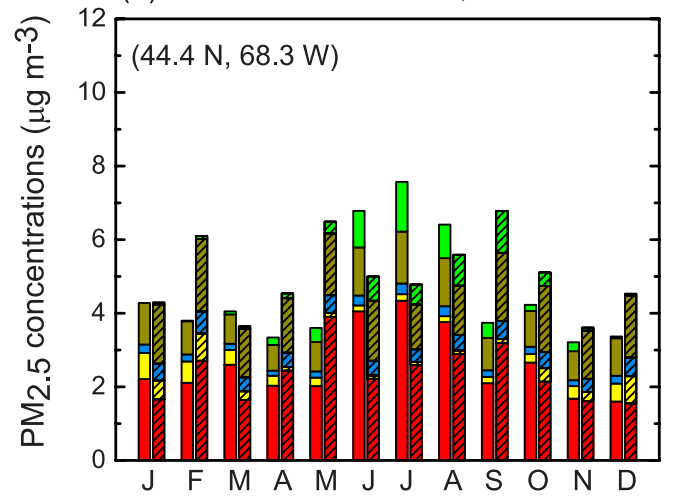

(c) Washington, DC

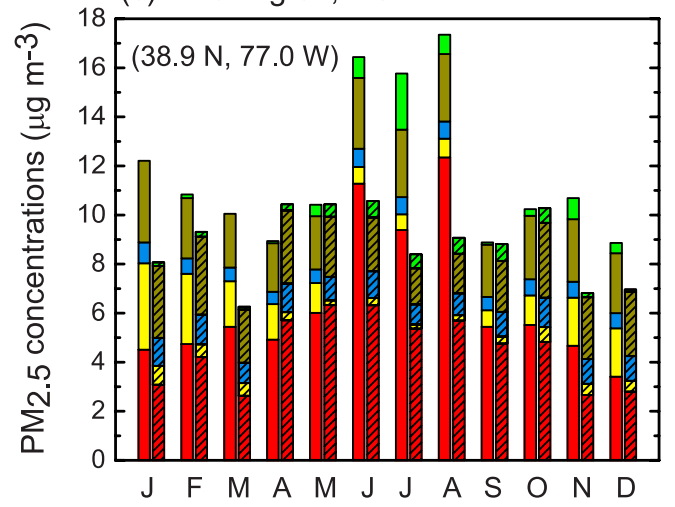

(e) Caney Creek, AR
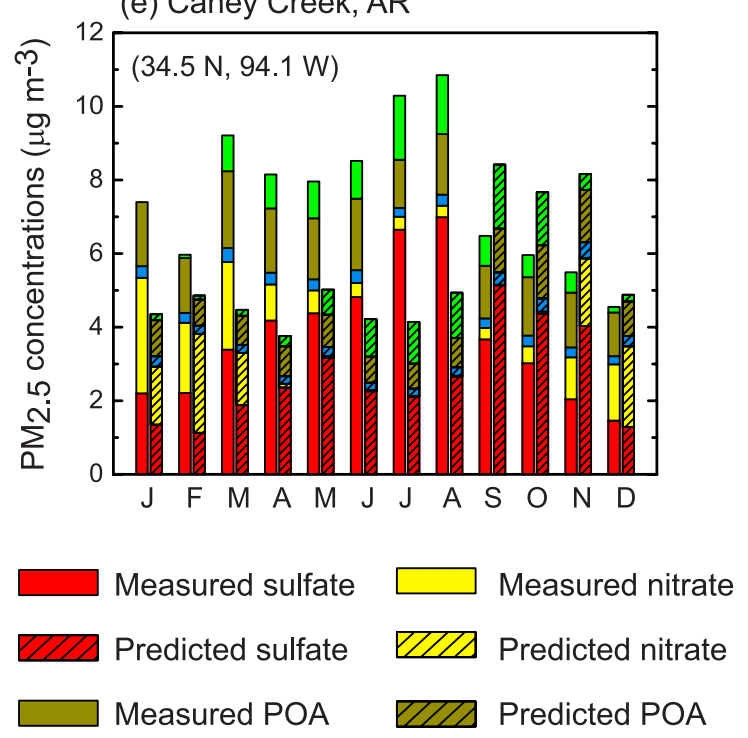

(b) Lye Brook Wilderness, VT

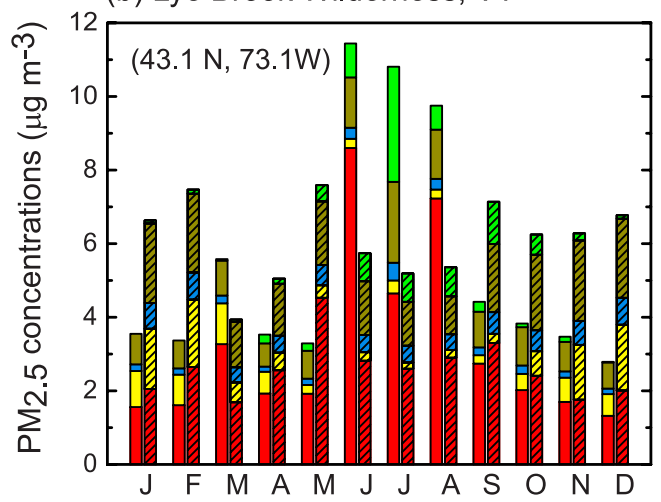

(d) Breton, LA
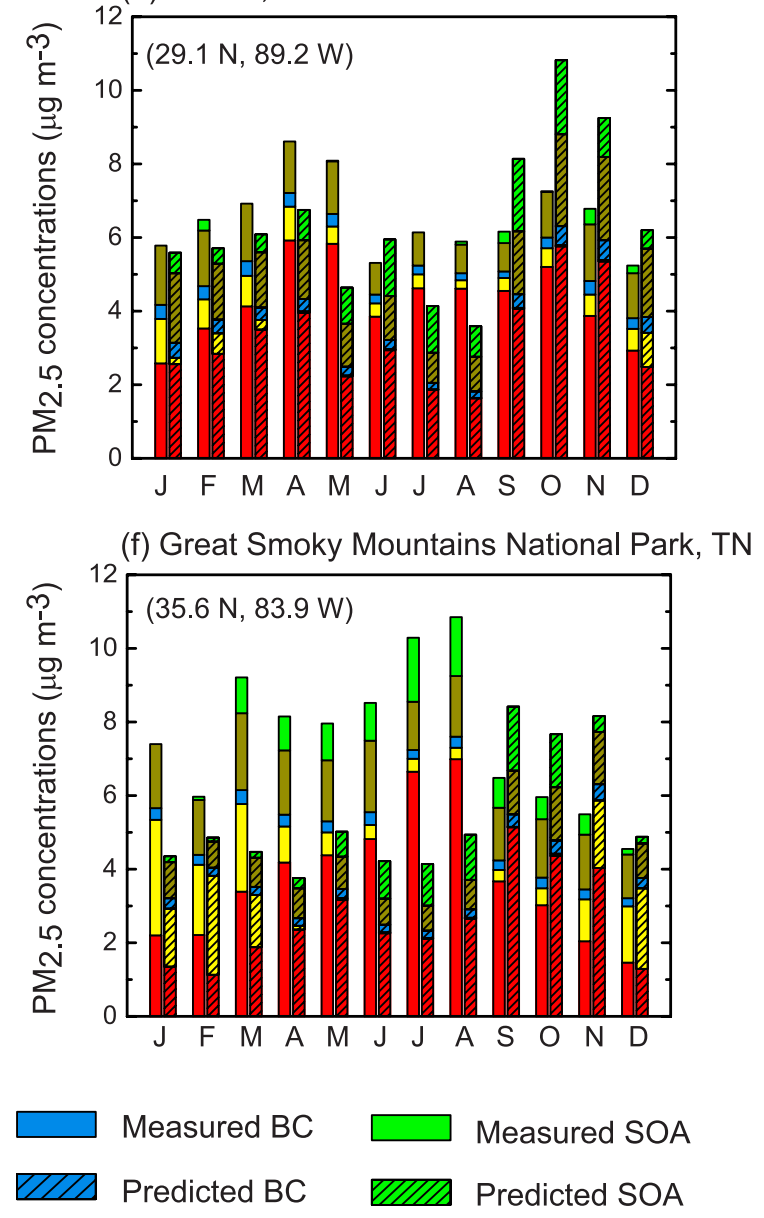

Figure 6. Seasonal cycles of concentrations $\left(\mu \mathrm{g} \mathrm{m}^{-3}\right)$ of ammonium sulfate (calculated as $1.37 \times$ $\left[\mathrm{SO}_{4}{ }^{2-}\right]$ [Malm et al., 1994]), ammonium nitrate (calculated as $1.29 \times\left[\mathrm{NO}^{3-}\right]$ [Malm et al., 1994]), BC, POA, SOA, and $\mathrm{PM}_{2.5}$ at selected sites. Bars on the left are IMPROVE data, and those on the right are model predictions. See text for the calculation of $\mathrm{PM}_{2.5}$ mass and estimates of measured POA and SOA. Name and location of each site are indicated.

air quality, a question one would ask is how the uncertainties associated with the GISS GCM meteorological fields influence the predicted atmospheric components. Wu et al [2007] have shown that the GISS GCM fields provide a simulation of tropospheric ozone and its precursors that is consistent with the simulations driven by NASA/GEOS assimilated meteorological data for year 2001 (GEOS-3 and GEOS-4). Aerosols differ from the gas phase species in that predicted concentrations of aerosols are very sensitive to precipitation/wet deposition. We evaluate in Figure 9 the model's performance in predicting wet deposition by comparing the predicted wet deposition fluxes of $\mathrm{SO}_{4}^{2-}$ ion 
(g) Badlands National Park, SD

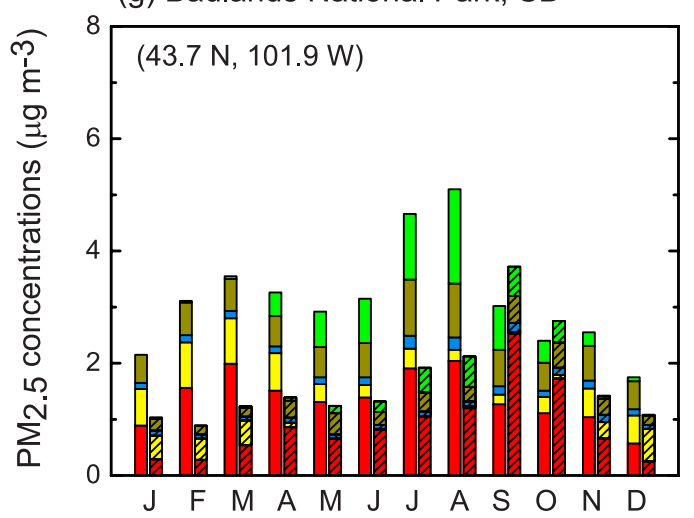

(i) Mount Rainier National Park, WA

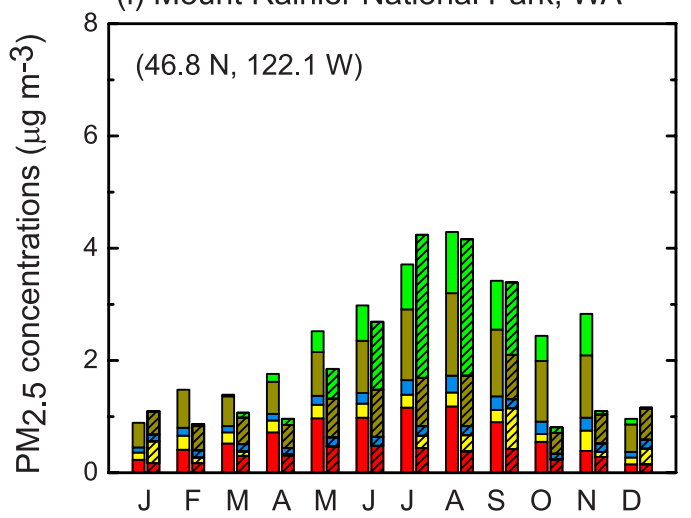

(h) Mount Hood, OR

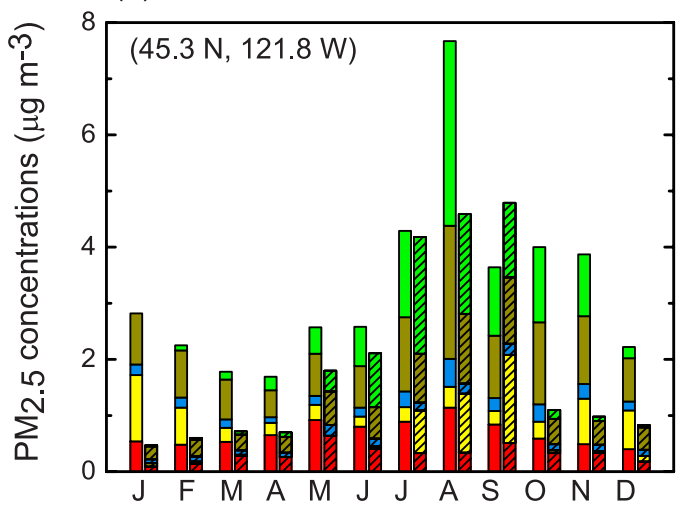

(j) Snoqualamie Pass, WA
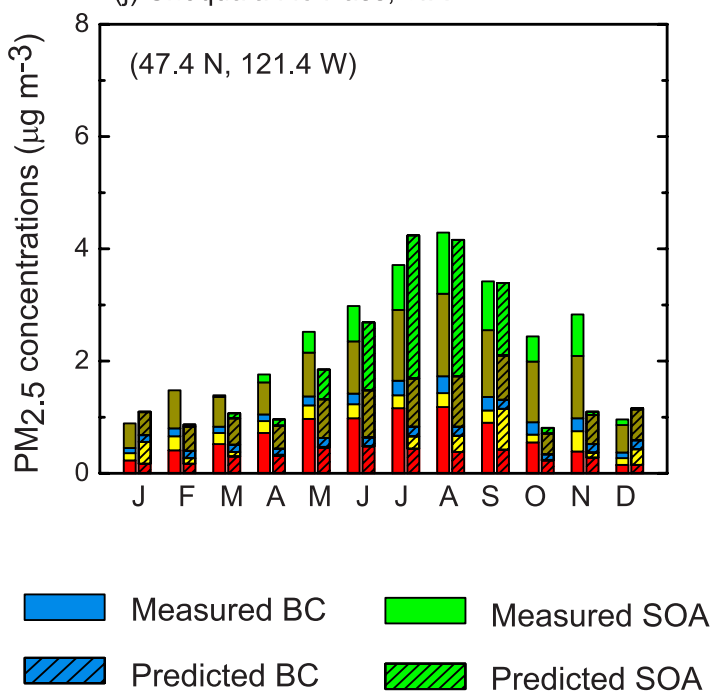

Measured BC

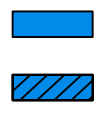

Predicted BC
IIIIA Predicted SOA
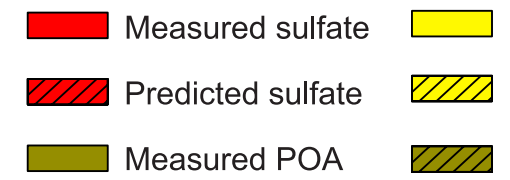

Measured nitrate

Predicted nitrate

Predicted POA

Figure 6. (continued)

to measurements at 223 sites from the National Atmospheric Deposition Program (NADP) network (http://nadp.sws.uiuc. edu/). The sites span the continental United States and the observed wet deposition fluxes of sulfate are averaged over 2001-2003. The model reproduces well the measured wet deposition of $\mathrm{SO}_{4}^{2-}$ with a slope of 1.02 and a correlation coefficient of 0.86 , reflecting the accurate representation of wet deposition by the model.

\subsection{Contribution of SOA to Fine PM Mass Over the United States}

[29] Comparisons between predicted annual mean concentrations of SOA (Figure 3 ) and those of measured sulfate, nitrate and $\mathrm{BC}$ (Figure 8) indicate that SOA is significant even on an annual mean basis. In the southeastern United States, predicted annual mean SOA concentrations of about $1 \mu \mathrm{g} \mathrm{m}^{-3}$ are about the same as measured nitrate concentrations and exceed measured BC levels. In the western United States, predicted annual mean SOA concentrations of about $0.4-0.7 \mu \mathrm{g} \mathrm{m}^{-3}$ are comparable to measured values of nitrate and $\mathrm{BC}$, except that SOA levels are lower than measured nitrate concentrations over southern California.

[30] The importance of SOA aerosol can also be seen in Figure 6. In summer, predicted SOA concentrations are comparable to those of nitrate and $\mathrm{BC}$ at the three northeastern sites (Arcadia National Park in Maine, Lye Brook Wilderness in Vermont, and Washington, DC, Figures $6 \mathrm{a}-6 \mathrm{c}$ ), and they are as abundant as POA and higher than levels of $\mathrm{BC}$ and nitrate at three southeastern sites in the states of Louisiana, Arkansas, and Tennessee (Figures 6d-6f). At the three western sites (Mount Hood in Oregon and Mount Rainier National Park and Snoqualamie Pass in Washington) shown in Figures $6 \mathrm{~g}-6 \mathrm{j}$, SOA concentrations are predicted to exceed those of sulfate, nitrate, or BC in June-September.

[31] Figure 10a shows the annual mean ratios of predicted concentrations of SOA to those of predicted fine $\left(\mathrm{PM}_{2.5}\right)$ aerosol mass. On an annual basis, SOA is predicted to contribute to $\mathrm{PM}_{2.5}$ mass by $10-20 \%$ in the southeastern, as high as $38 \%$ in the northwestern, and about $5-15 \%$ in the rest of the United States. Although $\mathrm{PM}_{2.5}$ concentrations are underpredicted by about $20 \%$ over the United States 
(a)

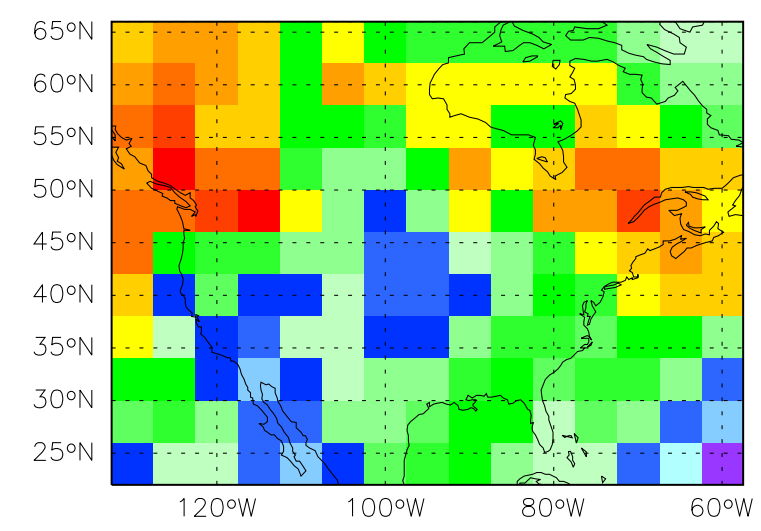

(c)

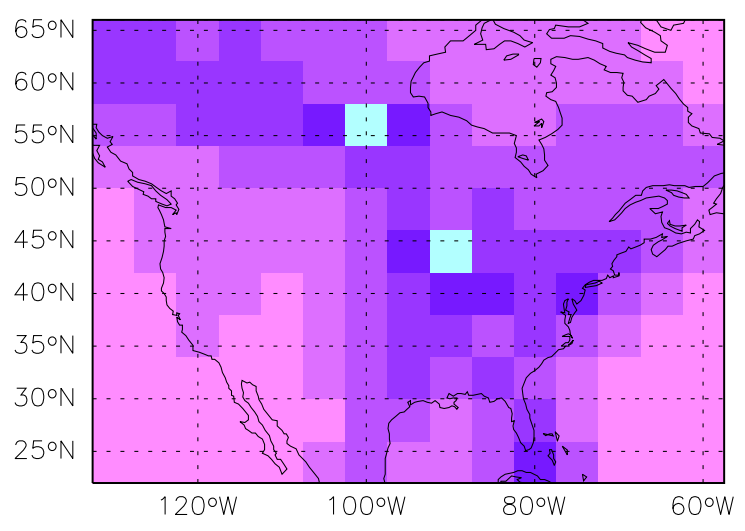

(b)

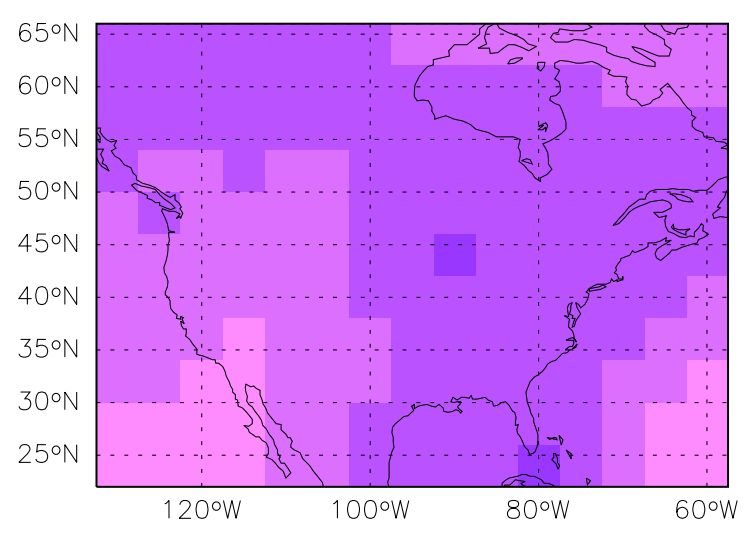

(d)

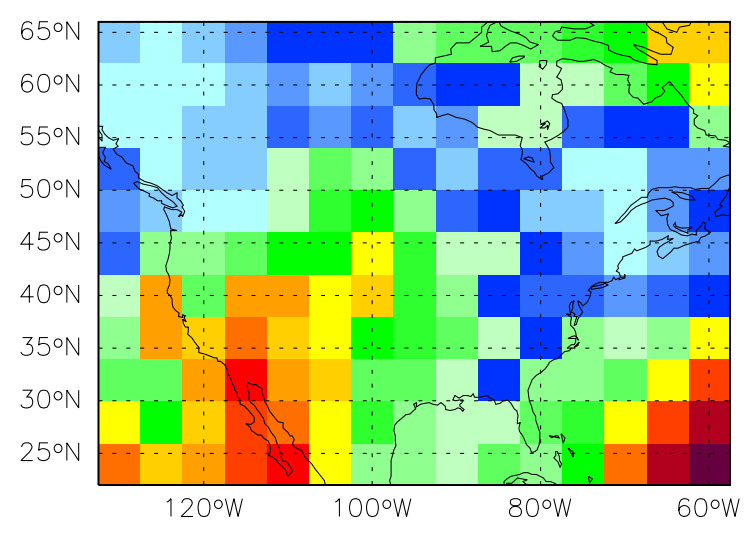

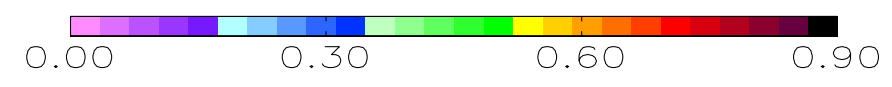

Figure 7. Annual mean ratio of SOA mass to total SOA concentration at the surface layer resulting from the oxidation of (a) hydrocarbon classes I-III, (b) class IV, (c) class V, and (d) isoprene. See Table 2 for the definition of hydrocarbon classes $\mathrm{I}-\mathrm{V}$.

(Table 6), SOA to $\mathrm{PM}_{2.5}$ ratios still indicate the importance of SOA.

[32] Ratios of SOA to $\mathrm{PM}_{2.5}$ exhibit large seasonal variations. On the basis of the predicted monthly aerosol concentrations at the 10 sites shown in Figure 6, the seasonal variations of the ratios of SOA to $\mathrm{PM}_{2.5}$ are calculated and presented in Figure 10b. As expected, ratios of SOA to $\mathrm{PM}_{2.5}$ are highest in the months of JuneSeptember, with SOA contributing to $5-25 \%$ of $\mathrm{PM}_{2.5}$ mass at most of these 10 sites. The SOA to $\mathrm{PM}_{2.5}$ ratios of about 0.5-0.6 at Mount Rainier National Park and Snoqualamie Pass in summer are a result of the overestimates of $\mathrm{OA}$ at these two sites.

\section{Conclusions and Discussions}

[33] Present-day aerosol levels over the United States are simulated using the chemical transport model GEOSCHEM (version 7.3.3) driven by the archived meteorological fields from the GISS GCM III. Predicted concentrations of each aerosol species have been evaluated using the IMPROVE measurements averaged over 2001-2003. The model reproduces fairly well the concentrations of sulfate (MB of $-0.49 \mu \mathrm{g} \mathrm{m}^{-3}, \mathrm{NMB}$ of $\left.-25.9 \%\right), \mathrm{BC}\left(-0.004 \mu \mathrm{g} \mathrm{m}^{-3}\right.$, $-1.9 \%)$, OA (POA + SOA) $\left(-0.56 \mu \mathrm{g} \mathrm{m}^{-3},-34.2 \%\right)$, and $\mathrm{PM}_{2.5}\left(-0.87 \mu \mathrm{g} \mathrm{m}^{-3},-20.4 \%\right)$. Predicted $\mathrm{BC}$ has a low bias (NMB: $-24.2 \%$ ) in the western (west of $95^{\circ} \mathrm{W}$ ) and a high bias (NMB: $+28.7 \%$ ) in the eastern United States. The model has the poorest performance in predicting nitrate aerosol, with NMBs of $+75.6 \%$ and $-54.4 \%$ in the western

Table 7. Parent Hydrocarbon Contributions to SOA Burdens Over the United States and Globally

\begin{tabular}{ccc}
\hline & \multicolumn{2}{c}{ Percent Contribution to SOA } \\
\cline { 2 - 3 } Hydrocarbon Class & USA & Global \\
\hline I-III & 39.5 & 33.3 \\
IV & 5.3 & 4.0 \\
V & 5.7 & 4.5 \\
Isoprene & 49.5 & 58.2 \\
\hline
\end{tabular}


(a)
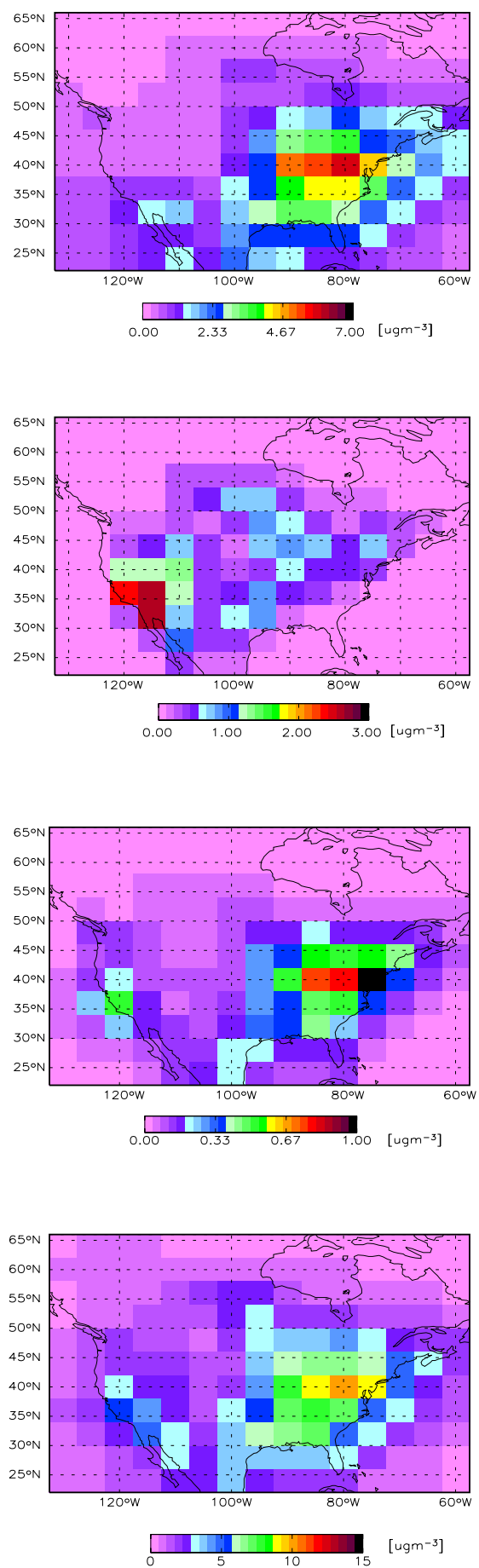

(b)
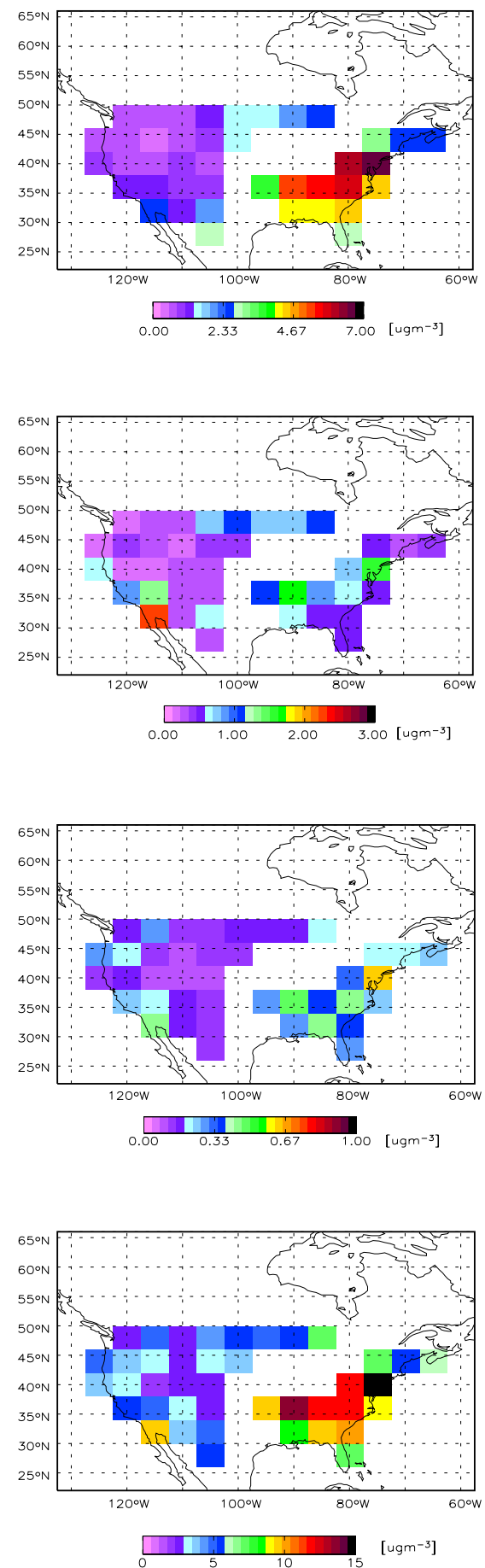

(c)
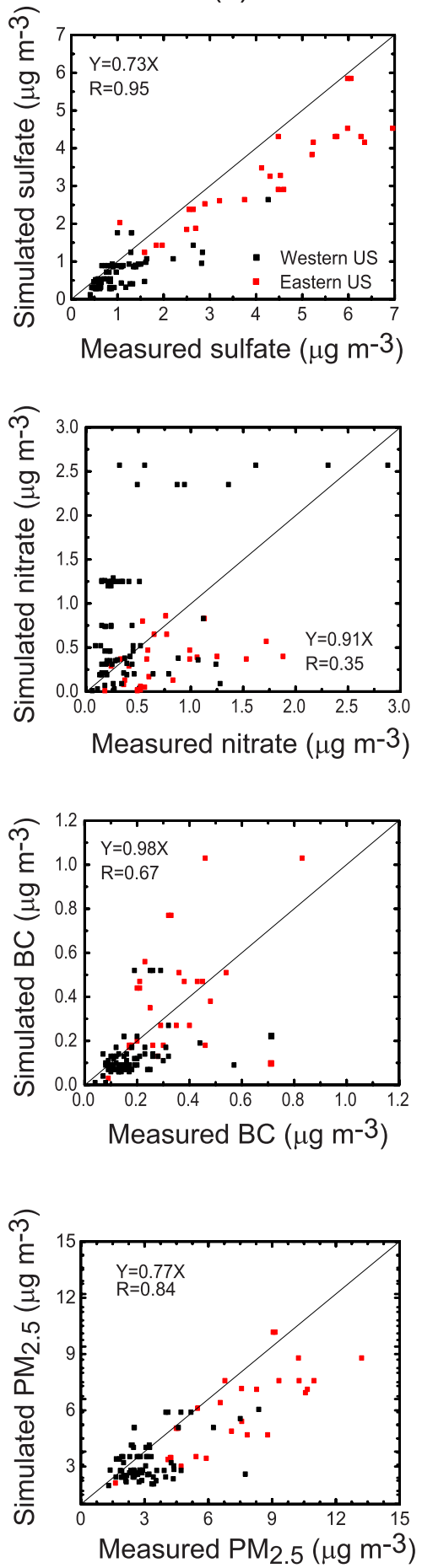

Figure 8. (a) Simulated annual mean distributions, (b) observed annual mean concentrations, and (c) simulated versus observed annul mean concentrations of sulfate (calculated as $1.37 \times\left[\mathrm{SO}_{4}{ }^{2-}\right][\mathrm{Malm}$ et al., 1994], first row), nitrate (calculated as $1.29 \times\left[\mathrm{NO}_{3}{ }^{-}\right]$[ Malm et al., 1994], second row), $\mathrm{BC}$ (third row), and $\mathrm{PM}_{2.5}$ mass (calculated using equation (3) in the text, fourth row). For scatterplots, concentrations of each species are given in Tables 4 and 5. Sites in the western and eastern United States are indicated by black and red data points, respectively. The boundary between the western and eastern United States is taken as $95^{\circ} \mathrm{W}$. The solid line represents the $y=x$ relation. The regression equation and correlation coefficient $R$ for linear fit through origin are indicated. 
and the eastern United States, respectively. The uncertainties with the emission inventories, heterogeneous reactions, as well as the bias intrinsic in the IMPROVE nitrate measurements might have influenced the comparisons between modeled nitrate concentrations with observations.

[34] Formation of SOA from terpenes and ORVOCs [Chung and Seinfeld, 2002] and isoprene [Henze and Seinfeld, 2006] is considered in this study. Levels of simulated OA (POA + SOA) lie mostly within the range of IMPROVE measurements. Concentrations and seasonal variation of OA over the eastern United States are simulated reasonably well, but $\mathrm{OA}$ is underestimated at the western sites. A sensitivity study shows that underestimation of POA emissions might be the cause of underprediction of $\mathrm{OA}$ in the western United States.

[35] Predicted SOA concentrations are comparable to those of nitrate and $\mathrm{BC}$ throughout the United States. On an annual basis, SOA is predicted to contribute $10-20 \%$ of $\mathrm{PM}_{2.5}$ mass in the southeastern, as high as $38 \%$ in the northwestern, and about $5-15 \%$ in the rest of the United States. The SOA fraction of $\mathrm{PM}_{2.5}$ has a strong seasonal variation, peaking in the months of June-September. SOA formation from isoprene is predicted to contribute about $30-35 \%$ of surface layer SOA formed over the southeastern and northwestern United States, the two areas with the highest SOA levels. Overall, isoprene is predicted to contribute $49.5 \%$ of the biogenic SOA burden over the United States.

[36] The results presented here indicates that the GISS GCM III/GEOS-CHEM model is a suitable tool for simulating aerosols over the United States in the present climate and lend support for evaluating effects of climate change on future aerosol levels. A number of factors contribute to

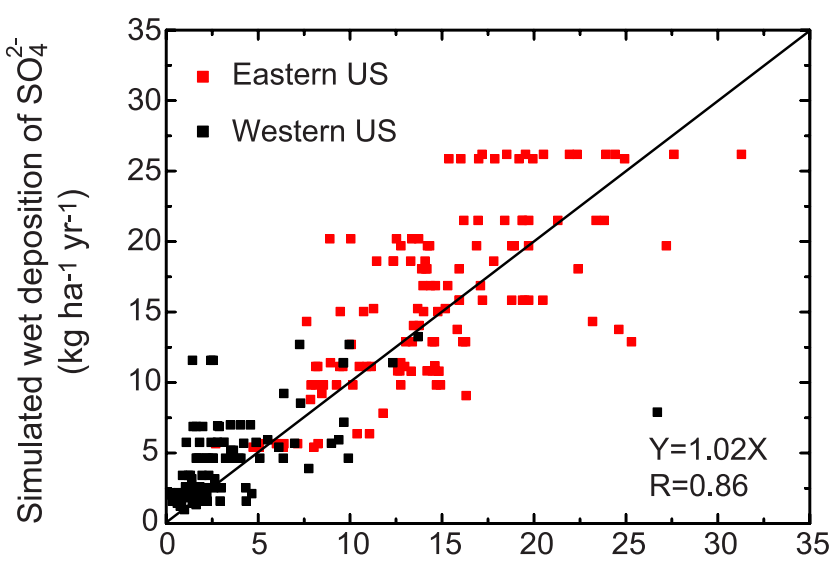

$$
\text { NADP wet deposition of } \mathrm{SO}_{4}^{2-}\left(\mathrm{kg} \mathrm{ha}^{-1} \mathrm{yr}^{-1}\right)
$$

Figure 9. Scatterplot of simulated versus observed wet deposition fluxes of $\mathrm{SO}_{4}{ }^{2-}$ ion $\left(\mathrm{kg} \mathrm{ha}^{-1} \mathrm{yr}^{-1}\right)$ at 223 sites from NADP network. Measured values are averaged over 2001-2003. Sites in the western and eastern United States are indicated by black and red data points, respectively. The boundary between the western and eastern United States is taken as $95^{\circ} \mathrm{W}$. The solid line represents the $y=x$ relation. The regression equation and correlation coefficient $R$ for linear fit through origin are indicated. (a)

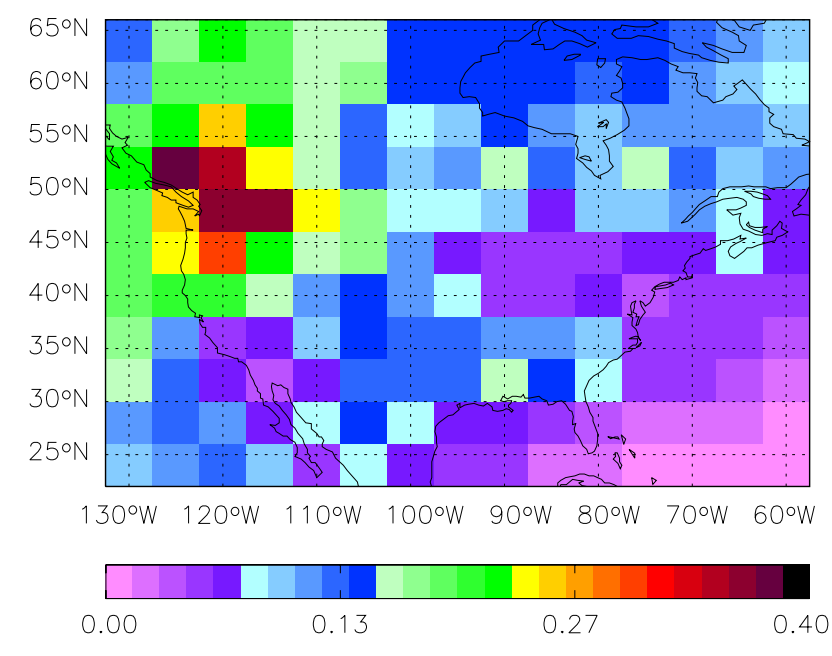

(b)

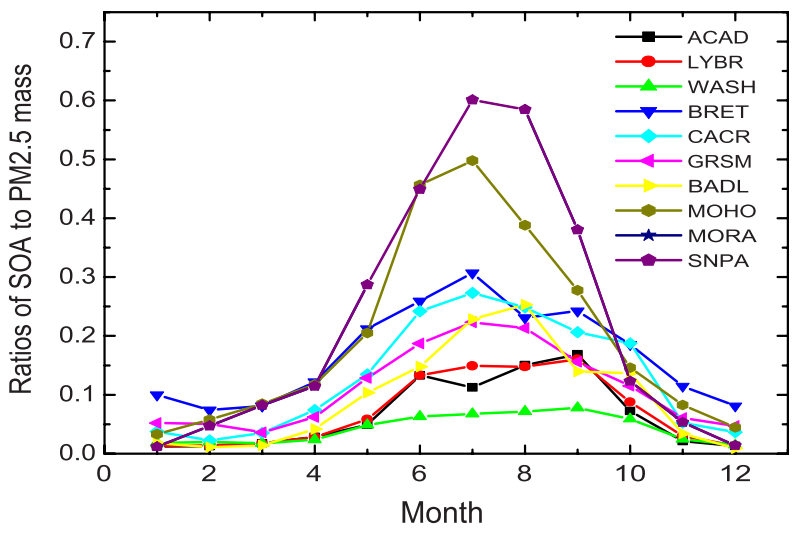

Figure 10. (a) Annual mean ratios of predicted concentrations of SOA to those of predicted fine $\left(\mathrm{PM}_{2.5}\right)$ aerosol mass. (b) Seasonal variations of the predicted ratios of SOA to $\mathrm{PM}_{2.5}$ for the 10 sites shown in Figure 5. ACAD, Acadia National Park, ME $\left(44.4^{\circ} \mathrm{N}, 68.3^{\circ} \mathrm{W}\right)$; LYBR, Lye Brook Wilderness, VT $\left(43.1^{\circ} \mathrm{N}, 73.1^{\circ} \mathrm{W}\right)$; WASH, Washington, DC $\left(38.9^{\circ} \mathrm{N}, 77.0^{\circ} \mathrm{W}\right)$; BRET, Breton, LA $\left(29.1^{\circ} \mathrm{N}\right.$, 89.2 $\left.{ }^{\circ} \mathrm{W}\right)$; CACR, Caney Creek, AR $\left(34.5^{\circ} \mathrm{N}, 94.1^{\circ} \mathrm{W}\right)$; GRSM, Great Smoky Mountains National Park, TN $\left(35.6^{\circ} \mathrm{N}, 83.9^{\circ} \mathrm{W}\right)$; BADL, Badlands National Park, SD $\left(43.7^{\circ} \mathrm{N}, 101.9^{\circ} \mathrm{W}\right) ; \mathrm{MOHO}$, Mount Hood, OR $\left(45.3^{\circ} \mathrm{N}\right.$, $\left.121.8^{\circ} \mathrm{W}\right)$; MORA, Mount Rainier National Park, WA $\left(46.8^{\circ} \mathrm{N}, 122.1^{\circ} \mathrm{W}\right) ; \mathrm{SNPA}$, Snoqualamie Pass, WA $\left(47.4^{\circ} \mathrm{N}\right.$, $\left.121.4^{\circ} \mathrm{W}\right) . \mathrm{PM}_{2.5}$ mass is calculated using equation (3).

uncertainties in the current results. The first factor is uncertainties in gas and particle emission inventories that underlie any prediction of climatological aerosol levels; such inventories are undergoing continuing improvement. A second factor relates to the applicability of laboratoryderived SOA yields to the ambient atmosphere. Recent laboratory chamber experiments have significantly approached ambient conditions in terms of concentration levels of hydrocarbon precursors and $\mathrm{NO}_{\mathrm{x}}$ conditions. The $\mathrm{NO}_{\mathrm{x}}$ level has been found to be crucial to SOA yield, and recent studies 
more closely approximate ambient hydrocarbon to $\mathrm{NO}_{\mathrm{x}}$ ratios. Whereas the data on isoprene SOA yield reflect these latest findings, the parameters employed for the other biogenic hydrocarbon precursors do not necessarily reflect the strong $\mathrm{NO}_{\mathrm{x}}$ dependence of SOA yield. Thus future studies are needed to better evaluate SOA yield of terpenes at the low $\mathrm{NO}_{\mathrm{x}}$ levels characteristic of remote regional areas. Cloud processing of isoprene oxidation products [Lim et al., 2005] has not been considered here; these could increase predicted SOA yields from isoprene. Condensation onto other (nonorganic) aerosol species could increase SOA formation from all precursors [Tsigaridis and Kanakidou, 2003]. Finally, we have investigated here only SOA from biogenic hydrocarbon precursors; as noted, the contribution from anthropogenic aromatics is the subject of future work.

[37] Acknowledgment. This work was supported by the U.S. Environmental Protection Agency under Science to Achieve Results (STAR) grant R830959. Hong Liao was partially supported by the 100-Talent Project of Chinese Academy of Sciences.

\section{References}

Adams, P. J., J. H. Seinfeld, and D. M. Koch (1999), Global concentrations of tropospheric sulfate, nitrate, and ammonium aerosol simulated in a general circulation model, J. Geophys. Res., 104, 13,791-13,824.

Ames, R. B., and W. C. Malm (2001), Comparison of sulfate and nitrate particle mass concentrations measured by IMPROVE and the CDN, Atmos. Environ., 35, 905-916.

Andersson-Sköld, Y., and D. Simpson (2001), Secondary organic aerosol formation in northern Europe: A model study, J. Geophys. Res., 106, $7357-7374$.

Bonn, B., R. von Kuhlmann, and M. G. Lawrence (2004), High contribution of biogenic hydroperoxides to secondary organic aerosol formation, Geophys. Res. Lett., 31, L10108, doi:10.1029/2003GL019172.

Chung, S. H., and J. H. Seinfeld (2002), Global distribution and climate forcing of carbonaceous aerosols, J. Geophys. Res., 107(D19), 4407, doi:10.1029/2001JD001397.

Cooke, W. F., C. Liousse, H. Cachier, and J. Feichter (1999), Construction of a $1^{\circ} \times 1^{\circ}$ fossil fuel emission data set for carbonaceous aerosol and implementation and radiative impact in the ECHAM4 model, J. Geophys. Res., 104(D18), 22,137-22,162.

de Gouw, J. A., et al. (2005), Budget of organic carbon in a polluted atmosphere: Results from the New England Air Quality Study in 2002, J. Geophys. Res., 110, D16305, doi:10.1029/2004JD005623.

Derwent, R. G., W. J. Collins, M. E. Jenkin, C. E. Johnson, and D. S. Stevenson (2003), The global distribution of secondary particulate matter in a 3-D Lagrangian chemistry transport model, J. Atmos. Chem., 44, $57-$ 95.

Duncan, B. N., R. V. Martin, A. C. Staudt, R. Yevich, and J. A. Logan (2003), Interannual and seasonal variability of biomass burning emissions constrained by satellite observations, J. Geophys. Res., 108(D2), 4100, doi:10.1029/2002JD002378.

Evans, M. J., and D. J. Jacob (2005), Impact of new laboratory studies of $\mathrm{N}_{2} \mathrm{O}_{5}$ hydrolysis on global model budgets of tropospheric nitrogen oxides, ozone, and OH, Geophys. Res. Lett., 32, L09813, doi:10.1029/ 2005GL022469.

Fiore, A. M., D. J. Jacob, I. Bey, R. M. Yantosca, B. D. Field, A. C. Fusco, and J. G. Wilkinson (2002), Background ozone over the United States in summer: Origin, trend, and contribution to pollution episodes, J. Geophys. Res., 107(D15), 4275, doi:10.1029/2001JD000982.

Fiore, A. M., D. J. Jacob, R. Mathur, and R. V. Martin (2003), Application of empirical orthogonal functions to evaluate ozone simulations with regional and global models, J. Geophys. Res., 108(D14), 4431, doi:10.1029/2002JD003151

Griffin, R. J., D. R. Cocker III, R. C. Flagan, and J. H. Seinfeld (1999a), Organic aerosol formation from the oxidation of biogenic hydrocarbons, J. Geophys. Res., 104, 3555-3568.

Griffin, R. J., D. Dabdub, D. R. Cocker III, and J. H. Seinfeld (1999b), Estimate of global atmospheric organic aerosol from oxidation of biogenic hydrocarbons, Geophys. Res. Lett., 26, 2721-2724.

Griffin, R. J., D. Dabdub, M. J. Kleeman, M. P. Fraser, G. R. Cass, and J. H. Seinfield (2002), Secondary organic aerosol: 3. Urban/regional scale model of size- and composition-resolved aerosols, J. Geophys. Res., 107(D17), 4334, doi:10.1029/2001JD000544.

Guenther, A., et al. (1995), A global model of natural volatile organic compound emissions, J. Geophys. Res., 100, 8873-8892.

Guenther, A., T. Karl, P. Harley, C. Wiedinmyer, P. I. Palmer, and C. Geron (2006), Estimates of global terrestrial isoprene emissions using MEGAN (Model of Emissions of Gases and Aerosols from Nature), Atmos. Chem. Phys. Disc., 6, 107-173.

Heald, C. L., D. J. Jacob, R. J. Park, L. M. Russell, B. J. Huebert, J. H. Seinfeld, H. Liao, and R. J. Weber (2005), A large organic aerosol source in the free troposphere missing from current models, Geophys. Res. Lett., 32, L18809, doi:10.1029/2005GL023831.

Henze, D. K., and J. H. Seinfeld (2006), Global secondary organic aerosol formation from isoprene oxidation, Geophys. Res. Lett., 33, L09812, doi:10.1029/2006GL025976.

Jacob, D. J. (2000), Heterogeneous chemistry and tropospheric ozone, Atmos. Environ., 34, 2131-2159.

Kanakidou, M., et al. (2005), Organic aerosol and global climate modeling: A review, Atmos. Chem. Phys., 5, 1053-1123.

Kroll, J. H., N. L. Ng, S. M. Murphy, R. C. Flagan, and J. H. Seinfeld (2006), Secondary organic aerosol formation from isoprene photooxidation, Environ. Sci. Technol., 40, 1869-1877, doi:10.1021/ es0524301.

Lack, D. A., X. X. Tie, N. D. Bofinger, A. N. Wiegand, and S. Madronich (2004), Seasonal variability of secondary organic aerosol: A global modeling study, J. Geophys. Res., 109, D03203, doi:10.1029/2003JD003418.

Li, Q., et al. (2002), Transatlantic transport of pollution and its effects on surface ozone in Europe and North America, J. Geophys. Res., 107(D13), 4166, doi:10.1029/2001JD001422.

Li, Q. B., D. J. Jacob, R. M. Yantosca, J. W. Munger, and D. D. Parrish (2004), Export of $\mathrm{NO}_{\mathrm{y}}$ from the North American boundary layer: Reconciling aircraft observations and global model budgets, J. Geophys. Res., 109, D02313, doi:10.1029/2003JD004086.

Liao, H., and J. H. Seinfeld (2005), Global impacts of gas-phase chemistryaerosol interactions on direct radiative forcing by anthropogenic aerosols and ozone, J. Geophys. Res., 110, D18208, doi:10.1029/2005JD005907. Liao, H., P. J. Adams, S. H. Chung, J. H. Seinfeld, L. J. Mickley, and D. J. Jacob (2003), Interactions between tropospheric chemistry and aerosols in a unified general circulation model, J. Geophys. Res., 108(D1), 4001, doi:10.1029/2001JD001260.

Liao, H., J. H. Seinfeld, P. J. Adams, and L. J. Mickley (2004), Global radiative forcing of coupled tropospheric ozone and aerosols in a unified general circulation model, J. Geophys. Res., 109, D16207, doi:10.1029/ 2003JD004456.

Liao, H., W-T. Chen, and J. H. Seinfeld (2006), Role of climate change in global predictions of future tropospheric ozone and aerosols, J. Geophys. Res., 111, D12304, doi:10.1029/2005JD006852.

Lim, H. J., and B. J. Turpin (2002), Origins of primary and secondary organic aerosol in Atlanta: Results of time-resolved measurements during the Atlanta supersite experiment, Environ. Sci. Technol., 36, 4489-4496.

Lim, H. J., A. G. Carlton, and B. J. Turpin (2005), Isoprene forms secondary organic aerosol through cloud processing: Model simulations, Environ. Sci. Technol., 39, 4441-4446.

Limbeck, A., and H. Puxbaum (2000), Dependence of in-cloud scavenging of polar organic aerosol compounds on the water solubility, J. Geophys. Res., 105, 19,857-19,867.

Liu, H., D. J. Jacob, I. Bey, and R. M. Yantosca (2001), Constraints from ${ }^{210} \mathrm{~Pb}$ and ${ }^{7} \mathrm{Be}$ on wet deposition and transport in a global three-dimensional chemical tracer model driven by assimilated meteorological fields, J. Geophys. Res., 106(D11), 12,109-12,128.

Malm, W. C., J. F. Sisler, D. Huffman, R. A. Eldred, and T. A. Cahill (1994), Spatial and seasonal trends in particle concentration and optical extinction in the United States, J. Geophys. Res., 99, 1347-1370.

Mari, C., D. J. Jacob, and P. Bechtold (2000), Transport and scavenging of soluble gases in a deep convective cloud, J. Geophys. Res., 105, 22,25522,267 .

Martin, R. V., D. J. Jacob, R. M. Yantosca, M. Chin, and P. Ginoux (2003), Global and regional decreases in tropospheric oxidants from photochemical effects of aerosols, J. Geophys. Res., 108(D3), 4097, doi:10.1029/ 2002JD002622.

Millet, D. B., N. M. Donahue, S. N. Pandis, A. Polidori, C. O. Stanier, B. J. Turpin, and A. H. Goldstein (2005), Atmospheric volatile organic compound measurements during the Pittsburgh Air Quality Study: Results, interpretation, and quantification of primary and secondary contributions, J. Geophys. Res., 110, D07S07, doi:10.1029/2004JD004601.

Nenes, A., S. N. Pandis, and C. Pilinis (1998), ISORROPIA: A new thermodynamic equilibrium model for multiphase multicomponent inorganic aerosols, Aquat. Geochem., 4, 123-152.

Olson, J. (1992), World ecosystems (WE1.4): Digital raster data on a 10 minute geographic $1080 \times 2160$ grid, in Global Ecosystems 
Database, Version 1.0: Disc A, Natl. Geophys. Data Cent., Natl. Oceanic and Atmos. Admin., Boulder, Colo.

Park, R. J., D. J. Jacob, M. Chin, and R. V. Martin (2003), Sources of carbonaceous aerosols over the United States and implications for natural visibility, J. Geophys. Res., 108(D12), 4355, doi:10.1029/ 2002JD003190.

Park, R. J., D. J. Jacob, B. D. Field, R. M. Yantosca, and M. Chin (2004), Natural and transboundary pollution influences on sulfate-nitrateammonium aerosols in the United States: Implications for policy, J. Geophys. Res., 109, D15204, doi:10.1029/2003JD004473.

Park, R. J., D. J. Jacob, N. Kumar, and R. M. Yantosca (2006), Regional visibility statistics in the United States: Natural and transboundary pollution influences, and implications for the Regional Haze Rule, Atmos. Environ., 40, 5405-5423.

Polidori, A., B. J. Turpin, H. J. Lim, J. C. Cabada, R. Subramanian, S. N. Pandis, and A. L. Robinson (2006), Local and regional secondary organic aerosol: Insights from a year of semi-continuous carbon measurements at Pittsburgh, Environ. Sci. Technol., 40, 861-872.

Rind, D., J. Lerner, K. Shah, and R. Suozzo (1999), Use of on-line tracers as a diagnostic tool in general circulation model development: 2 . Transport between the troposphere and stratosphere, J. Geophys. Res., 104, 9151-9167.

Rind, D., J. Lerner, J. Jonas, and C. McLinden (2007), Effects of resolution and model physics on tracer transports in the GISS GCMs, J. Geophys. Res., doi:10.1029/2006JD007476, in press

Seinfeld, J. H., and J. F. Pankow (2003), Organic atmospheric particulate material, Annu. Rev. Phys. Chem., 54, 121-140.

Strader, R. L., F. Lurmann, and S. N. Pandis (1999), Evaluation of secondary organic aerosol formation in winter, Atmos. Environ., 33, 48494863.

Tsigaridis, K., and M. Kanakidou (2003), Global modeling of secondary organic aerosol in the troposphere: A sensitivity analysis, Atmos. Chem. Phys., 3, 1849-1869.

Tsigaridis, K., J. Lathiere, M. Kanakidou, and D. A. Hauglustaine (2005), Naturally driven variability in the global secondary organic aerosol over a decade, Atmos. Chem. Phys., 5, 1891-1904.
Turpin, B. J., and J. J. Huntzicker (1995), Identification of secondary organic aerosol episodes and quantification of primary and secondary organic aerosol concentration during SCAQS, Atmos. Environ., 29, $3527-3544$

U.S. Environmental Protection Agency (2004), Air quality criteria for particulate matter (October 2004), EPA 600/P-699/002aF-bF pp, Washington, D. C.

Wang, Y., D. J. Jacob, and J. A. Logan (1998), Global simulation of tropospheric $\mathrm{O}_{3}-\mathrm{NOx}$-hydrocarbon chemistry: 1 . Model formulation, J. Geophys. Res., 103, 10,713-10,725.

Wesely, M. L. (1989), Parameterization of surface resistances to gaseous dry deposition in regional-scale numerical models, Atmos. Environ., 23, $1293-1304$

Wu, S., L. J. Mickley, D. J. Jacob, J. A. Logan, R. M. Yantosca, and D. Rind (2007), Why are there large differences between models in global budgets of tropospheric ozone?, J. Geophys. Res., 112, D05302, doi:10.1029/2006JD007801.

Yevich, R., and J. A. Logan (2003), An assessment of biofuel use and burning of agricultural waste in the developing world, Global Biogeochem. Cycles, 17(4), 1095, doi:10.1029/2002GB001952.

D. K. Henze, Department of Chemical Engineering, California Institute of Technology, Pasadena, CA 91125, USA. (daven@caltech.edu)

H. Liao, LAPC, Institute of Atmospheric Physics, Chinese Academy of Sciences, Beijing 100029, China. (hongliao@mail.iap.ac.cn)

L. J. Mickley and S. Wu, Department of Earth and Planetary Sciences, Harvard University, Cambridge, MA 02138, USA. (mickley@fas.harvard. edu; wu18@fas.harvard.edu)

J. H. Seinfeld, Department of Environmental Science and Engineering, California Institute of Technology, 1200 East California Boulevard, Mail Code 210-41, Pasadena, CA 91125, USA. (seinfeld@caltech.edu) 